\title{
Different roles of water in secondary organic aerosol formation from toluene and isoprene
}

\author{
Long $\mathrm{Jia}^{1,2}$ and YongFu $\mathrm{Xu}^{1,2}$ \\ ${ }^{1}$ State Key Laboratory of Atmospheric Boundary Layer Physics and Atmospheric Chemistry, Institute of Atmospheric \\ Physics, Chinese Academy of Sciences, Beijing 100029, China \\ ${ }^{2}$ Department of Atmospheric Chemistry and Environmental Sciences, College of Earth Sciences, University of Chinese \\ Academy of Sciences, Beijing 100049, China
}

Correspondence: YongFu Xu (xyf@mail.iap.ac.cn)

Received: 17 November 2017 - Discussion started: 13 December 2017

Revised: 8 May 2018 - Accepted: 20 May 2018 - Published: 8 June 2018

\begin{abstract}
Roles of water in the formation of secondary organic aerosol (SOA) from the irradiations of toluene- $\mathrm{NO}_{2}$ and isoprene- $\mathrm{NO}_{2}$ were investigated in a smog chamber. Experimental results show that the yield of SOA from toluene almost doubled as relative humidity increased from 5 to $85 \%$, whereas the yield of SOA from isoprene under humid conditions decreased by 2.6 times as compared to that under dry conditions. The distinct difference of RH effects on SOA formation from toluene and isoprene is well explained with our experiments and model simulations. The increased SOA from humid toluene- $\mathrm{NO}_{2}$ irradiations is mainly contributed by $\mathrm{O}-\mathrm{H}$-containing products such as polyalcohols formed from aqueous reactions. The major chemical components of SOA in isoprene- $\mathrm{NO}_{2}$ irradiations are oligomers formed from the gas phase. SOA formation from isoprene$\mathrm{NO}_{2}$ irradiations is controlled by stable Criegee intermediates (SCIs) that are greatly influenced by water. As a result, high RH can obstruct the oligomerization reaction of SCIs to form SOA.
\end{abstract}

\section{Introduction}

Water is an important environmental factor that can influence the formation of secondary organic aerosol (SOA) through the physical or chemical processes, and is often represented with relative humidity $(\mathrm{RH})$ or liquid water content (LWC). Toluene and isoprene are two important precursors of SOA, which are representatives of volatile organic compounds (VOCs) from anthropogenic and biogenic sources.
Both toluene and isoprene can produce glyoxal during their oxidation processes in the atmosphere. As widely reported, glyoxal is a typical precursor of SOA formed in the aqueous phase (Volkamer et al., 2009; Lim et al., 2010, 2013; Ervens et al., 2011; Shen et al., 016). The difference is that toluene contains an aromatic ring, which is mainly oxidized by $\mathrm{OH}$ radicals, while isoprene contains two $\mathrm{C}=\mathrm{C}$ bonds, which can also be oxidized by $\mathrm{O}_{3}$ in addition to $\mathrm{OH}$. Thus, toluene and isoprene can provide insight into the roles of water in SOA formation from different kinds of VOCs.

Sadezky et al. $(2006,2008)$ reported that stable Criegee intermediates (SCIs) $\left(\mathrm{CH}_{2} \mathrm{OO}, \mathrm{C}_{2} \mathrm{H}_{4} \mathrm{OO}, \mathrm{C}_{3} \mathrm{H}_{6} \mathrm{OO}\right.$, and $\mathrm{C}_{4} \mathrm{H}_{8} \mathrm{OO}$ ) play a central role in SOA formation from the ozonolysis of ethyl butenyl ether, trans-3-hexene, 2, 3dimethyl-2-butene, and trans-4-octene. They further suggested that SCI-derived oligomers are formed by the reactions of $\mathrm{RO}_{2}$ with SCIs. Sakamoto et al. (2013) showed that the reactions of SCIs with hydroperoxides from ethylene can form SOA. Inomata et al. (2014) and Riva et al. (2017) showed that the reaction of an SCI with carboxylic acids or hydroperoxides can contribute to SOA formation from the ozonolysis of isoprene. Zhao et al. $(2015,2016)$ also showed that the SOA generated from the ozonolysis of trans3 -hexene and $\alpha$-cedrene is primarily composed of oligomers formed from the addition of SCIs to $\mathrm{RO}_{2}$ radicals. Although these studies have demonstrated the importance of SCIderived oligomers in SOA formation from the ozonolysis of alkenes, the role of SCIs in SOA formation from isoprene$\mathrm{NO}_{2}$ irradiations has not been reported. 
RH has a positive correlation with the mass yield of SOA from aromatics, such as p-xylene (Healy et al., 2009), toluene (Kamens et al., 2011; White et al., 2014), o-, p-xylene (Zhou et al., 2011), benzene and ethylebenzene (Jia and Xu, 2014). This has been mainly attributed to aqueous-phase reactions, such as active uptake of glyoxal in particle water. An exception is from the study of Cocker et al. (2001), who found that the yield of SOA from m-xylene and 1,3,5-trimethylbenzene in the presence of propene was unaffected by $\mathrm{RH}$ ( 5 and $50 \%$ ). This is probably due to the presence of propene in their reaction systems, which can reduce the $\mathrm{OH}$ radicals, leading to the decrease in the yield of SOA (Song et al., 2007).

SOA from isoprene has been widely studied, as summarized by Carlton et al. (2009). An earlier study from Dommen et al. (2006) showed that RH had little effect on the SOA yield from isoprene- $\mathrm{NO}_{x}\left(\mathrm{NO}, \mathrm{NO}_{2}\right)$ irradiations in the absence of seed particles at 2 and $84 \%$ RH. A study from Zhang et al. (2011) showed that RH had a negative effect on SOA formation from isoprene- $\mathrm{NO}_{x}$ irradiations with seed particles of $\left(\mathrm{NH}_{4}\right)_{2} \mathrm{SO}_{4}$ under two $\mathrm{RH}$ conditions (15-40 and 40-90\%) and ascribed the rise of SOA yield under lower RH to the enhancement of 2-methylglyceric acid (2-MG) and its corresponding oligomers. Nguyen et al. (2011b) found that RH did not affect the yields of SOA from isoprene in their isoprene- $\mathrm{NO}_{x}-\mathrm{H}_{2} \mathrm{O}_{2}$ irradiations without seed particles under dry (2\%) and humid (90\%) conditions, but they observed enhancement of 2-MG-derived oligomers under low RH, which is consistent with Zhang et al. (2011). Zhang et al. (2012) studied SOA formation from methacrolein (MACR, one of major products from isoprene) under different ratios of MACR / NO. Their results showed that the effect of RH on formation of SOA depended on the yields of SOA precursors (e.g., methacryloyl peroxynitrate, MPAN). In addition, isoprene-derived organosulfates (Zhang et al., 2011, 2012) and isoprene epoxydiols (IEPOX)derived products (Nguyen et al., 2014) are enhanced under higher RH. A recent study from Lewandowski et al. (2015) showed that the aerosol yield from isoprene-NO irradiations decreased with increasing RH (9 to $49 \%$ ). The role of water in SOA formation is so complex that more research is still required to understand mechanisms of SOA formation.

MPAN is one of key precursors of SOA from isoprene under high $\mathrm{NO}_{x}$ conditions (Surratt et al., 2010), which can react with $\mathrm{OH}$ to produce epoxides (methacrylic acid epoxide, MAE, hydroxymethyl-methyl-a-lactone, HMML). Lin et al. (2013) reported that MAE was an important precursor to 2-MG, a tracer of isoprene-derived SOA. Nguyen et al. (2015) showed that HMML could form SOA. Since SCIs, IEPOX, MPAN, HMML, and MAE co-exist in isoprene- $\mathrm{NO}_{2}$ irradiations, there are cross-reactions in the system. Thus, the study is still needed to demonstrate the role of these precursors in oligomer formation from isoprene- $\mathrm{NO}_{2}$ irradiations.

Both toluene and isoprene can produce glyoxal during their oxidation processes. Why was the positive effect of $\mathrm{RH}$ on the SOA yield of isoprene not observed? We consider that different chemical processes are likely responsible for the different effects of RH on the SOA yields from toluene and isoprene. One of the most important differences between isoprene and toluene reaction systems is oxidation pathways. To clarify the different mechanisms of SOA formed under different humid conditions, this paper presents the experimental results of mass yields and chemical components of SOA from toluene and isoprene under controlled RH conditions, as well as the explanation of the mechanism of SOA formation.

\section{Experimental section}

All the experiments were carried out in a $1.3 \mathrm{~m}^{3}$ FEP reactor (DuPont 500A, USA). The equipment and experimental procedures were similar to our previous works (Jia and $\mathrm{Xu}$, 2014, 2016; Ge et al., 2017). Thus, only a brief introduction is given here. Two ionizing air blowers were around the reactor to remove the electric charge on the surface of the reactor. A light source was provided by black lamps (F40BL, GE, USA), with a center wavelength of $365 \mathrm{~nm}$. The photolysis rate of $\mathrm{NO}_{2}$ was determined to be $0.35 \mathrm{~min}^{-1}$ inside the reactor. The humidity was controlled by bubbling the high pure water $\left(18.2 \mathrm{M} \Omega \mathrm{cm}\right.$ at $25^{\circ} \mathrm{C}$, Millipore/DirectQ3). $\mathrm{NaCl}$ seed particles were prepared by a constant output atomizer (Model 3076, TSI, USA).

Background air was prepared by a Zero Air Supply (model 111 and model 1150, Thermo Scientific, USA) with three additional VOC traps (BHT-4, Agilent). $\mathrm{NO}_{x}, \mathrm{O}_{3}$, and $\mathrm{SO}_{2}$ were measured by corresponding analyzers of Thermo model 42C, model 49C, and model 45i (trace level). The concentrations of $\mathrm{NO}_{x}, \mathrm{O}_{3}$, and $\mathrm{SO}_{2}$ in background air were determined to be less than $1 \mathrm{ppb}$. The particles in background air could not be detected with SMPS in the absence of irradiations, but the particle number concentration of $10^{4} \mathrm{~cm}^{-3}$ was obtained at an irradiation time of about $5 \mathrm{~h}$. From some experiments and model simulations the particles were considered to be $\mathrm{H}_{2} \mathrm{SO}_{4}$ (less than $1 \mu \mathrm{g} \mathrm{m}^{-3}$ ), which was formed from oxidation of $\mathrm{SO}_{2}$ by $\mathrm{OH}$ radicals.

Gas-phase organics were measured with a gas chromatograph-mass spectrometer (GC-MS: Agilent model 7890A GC and Agilent model 5975C mass selective detector, USA), which was equipped with a thermal desorber (Master TD, Dani, Italy). Particle number and mass concentrations were determined by SMPS (TSI model 3936, composed of DMS TSI 3080 and CPC TSI 3776). LWC was determined following the method of the reduced Dry-Ambient Aerosol Size Spectrometer (DAASS) (Engelhart et al., 2011). During the dry mode, the SMPS was modified by adding a large diameter Nafion dryer (Permapure MD-700-48F-3; the RH of the sample air can be reduced from 85 to $3.5 \%$ ) to the sampling inlet and a multi-tube Nafion dryer (Permapure PD-200T-24E-M; the $\mathrm{RH}$ of sheath can be reduced from 85 to $7 \%$ ) to sheath flow. 
During the humid mode, the humid air in SMPS was quickly replaced by humid air in the chamber by venting the sheath air at $10 \mathrm{~L} \mathrm{~min}^{-1}$, and then the humid aerosol was measured by SMPS. As a result, the LWC was determined by the difference of the particle mass concentrations between dry and humid modes.

To analyze the chemical components of SOA, the particles that ranged from 100 to $650 \mathrm{~nm}$ were collected on a $25 \mathrm{~mm}$ disk using a Dekati low-pressure impactor (DLPI, Dekati Ltd., Finland) at $10 \mathrm{~L} \mathrm{~min}^{-1}$. Organic functional groups of SOA were measured by a Fourier transform infrared (FTIR) spectrometer (Nicolet iS10, Thermo Scientific, USA). The mass spectra of SOA were measured by an electrospray ionization high-resolution mass spectrometer (ESIHRMS, Exactive-Orbitrap mass spectrometer, Thermo Scientific, USA). The average molecular size information of the humic-like substances (HULIS) present in SOA was determined by UV-Vis spectroscopy (Lambda 25, Perkin-Elmer, USA) based on the ratio of E2 / E3, in which E2 and E3 denote the absorbance at 250 and $365 \mathrm{~nm}$, respectively (Peuravuori and Pihlaja, 1997; Duarte et al., 2005).

The liquid reactants of toluene $(99.8 \%$ purity, Xilong Chemical Co., Ltd.), isoprene (99.9\% purity, Alfa Aesar), or $\mathrm{H}_{2} \mathrm{O}_{2}$ (30 weight $\%$ in $\mathrm{H}_{2} \mathrm{O}$ ) were injected into the airline and were evaporated with background air. $\mathrm{NO}_{2}\left(520 \mathrm{ppm}\right.$ in $\mathrm{N}_{2}$, Beijing Huayuan Gas Company) was injected into the reactor directly. For the experiments of the oxidation of isoprene by $\mathrm{OH}, \mathrm{OH}$ radicals were generated from the photolysis of $\mathrm{H}_{2} \mathrm{O}_{2}$ by UV lights (UVA-340, Q-Lab Corporation, USA). For the experiments of isoprene- $\mathrm{O}_{3}$ dark reaction, $\mathrm{O}_{3}$ was produced by an ozone generator with pure $\mathrm{O}_{2}(99.995 \%)$. N-hexane (>97\% purity, Beijing Tongguang Fine Chemicals Company) was used as an $\mathrm{OH}$ scavenger in the ozonolysis of isoprene. To evaluate the possible contributions of SOA from n-hexane in the ozonolysis of isoprene with nhexane, two experiments of the irradiations of hexane- $\mathrm{H}_{2} \mathrm{O}_{2}$ were performed for $6 \mathrm{~h}$, in which no SOA was observed by SMPS under both dry and humid conditions.

The initial conditions and purposes for the experiments are listed in Table 1, most of which are the irradiations of toluene- $\mathrm{NO}_{2}$ and isoprene- $\mathrm{NO}_{2}$. The initial concentrations of isoprene and toluene were about 0.90 and $0.85 \mathrm{ppm}$, respectively, and initial $\mathrm{NO}_{2}$ concentrations were about $320 \mathrm{ppb}$. At the end of each experiment, isoprene was almost completely consumed after $6 \mathrm{~h}$ reactions, and about $400 \mathrm{ppb}$ of toluene was reacted at the end of $7 \mathrm{~h}$ reactions. The $\mathrm{RH}$ was controlled to be dry $(6 \sim 10 \% \mathrm{RH})$ or humid $(78 \sim 88 \%$ $\mathrm{RH})$ conditions for different experiments. Two sets of experiments with artificially added $\mathrm{NaCl}$ seeds (about $10 \mu \mathrm{g} \mathrm{m}^{-3}$ ) were performed to quantify the role of particle water in SOA formation in humid toluene and isoprene reactions. To find out how RH affects the oxidation pathways of isoprene by $\mathrm{OH}$ and $\mathrm{O}_{3}$ in isoprene- $\mathrm{NO}_{2}$ irradiations, additional experiments of isoprene- $\mathrm{H}_{2} \mathrm{O}_{2}$ irradiations and isoprene- $\mathrm{O}_{3}$ reac- tions were carried out. The initial $\mathrm{H}_{2} \mathrm{O}_{2}$ and $\mathrm{O}_{3}$ concentrations were around 5 and $1.5 \mathrm{ppm}$, respectively.

To evaluate the potential contribution of SOA precursors (e.g., glyoxal, IEPOX, MPAN, HMML, MAE, and SCIs) from toluene and isoprene reaction systems, a model of the Master Chemical Mechanism (MCM v3.3.1, website: http: $/ / \mathrm{mcm}$.leeds.ac.uk/MCM, last access: 1 May 2016, Jenkin et al., 2015) was used, which includes the chamber-dependent reactions. To examine the influence of $\mathrm{RH}$ on oligomer formation from SCIs, the reactions of SCIs with carbonyls were added to MCM, which were expressed with $X+$ $\mathrm{SCI}=X(\mathrm{SCI})_{1}, X(\mathrm{SCI})_{1}+\mathrm{SCI}=X(\mathrm{SCI})_{2} \ldots X(\mathrm{SCI})_{n-1}+$ $\mathrm{SCI}=X(\mathrm{SCI})_{n}$, where $n=1-10$ and $X$ represents carbonyls. The rate constant for these reactions was set to be $5 \times 10^{-12} \mathrm{~cm}^{3}$ molecule ${ }^{-1} \mathrm{~s}^{-1}$ (Vereecken et al., 2012). Since most of $\mathrm{RO}_{2}$ was consumed by $\mathrm{NO}_{x}, \mathrm{SCI}+\mathrm{RO}_{2}$ reactions were not included in our model. The carbonyls were chosen based on the results of mass spectra data from isoprene- $\mathrm{NO}_{2}$ irradiations shown in Sect. 3.4. A set of ordinary differential equations was built and solved using Matlab.

\section{Results and discussion}

\subsection{RH effects on SOA yields}

\subsubsection{Determination of LWC}

The LWC in particles makes up a great percentage under humid conditions (as shown in Fig. 1). To calculate the yield of SOA, the LWC has to be excluded. On the other hand, since LWC was only measured at the end of the reaction, to obtain the time evolution of SOA concentrations we needed to deduct LWC during the whole reaction period. The value of LWC depends on chemical components of particles and environmental conditions (temperature and humidity). The volume growth factor (VGF) was used to estimate the contributions of LWC in particles, which was defined by Engelhart et al. (2011) as the ratio of the particle volume at humid air to the particle volume at dry air. Assuming that all the particles are spheres and have the same growth factor, the VGF is equal to the growth factor (GF) cubed as

$\mathrm{VGF}=\frac{V_{\text {hydrated }}}{V_{\text {dried }}}=\left(\frac{D_{\text {hydrated }}}{D_{\text {dried }}}\right)^{3}=\mathrm{GF}^{3}$.

$V_{\text {hydrated }}$ and $V_{\text {dried }}$ indicate the total measured volumes of hydrated or dried particles, respectively. $D_{\text {hydrated }}$ and $D_{\text {dried }}$ are the diameter of hydrated or dried particles, respectively, calculated from their volumes.

VGF is determined to be $1.28(\mathrm{GF}=1.09, \mathrm{RH}=78 \%)$ for the particles from toluene- $\mathrm{NO}_{2}$ irradiations, 1.18 $(\mathrm{GF}=1.06, \mathrm{RH}=79 \%)$ from isoprene- $\mathrm{NO}_{2}$ irradiations, $1.40(\mathrm{GF}=1.12, \mathrm{RH}=77 \%)$ from isoprene- $\mathrm{H}_{2} \mathrm{O}_{2}$ irradiations, and $1.30(\mathrm{GF}=1.09, \mathrm{RH}=88 \%)$ from isoprene- $\mathrm{O}_{3}$ reaction systems. There have been many studies about the 
Table 1. Experimental conditions of toluene and isoprene irradiations.

\begin{tabular}{|c|c|c|c|c|c|c|c|}
\hline VOCs & No. & $T / \mathrm{K}$ & $\mathrm{RH} / \%$ & $\mathrm{VOC} / \mathrm{ppm}$ & $\mathrm{NO} / \mathrm{ppb}$ & $\mathrm{NO}_{2} / \mathrm{ppb}$ & Aim \\
\hline \multirow{13}{*}{ Toluene } & 1 & 304 & 6 & 0.915 & 4.3 & 307.7 & \multirow{5}{*}{ SOA size and yield } \\
\hline & 2 & 304 & 85 & 0.804 & 5.3 & 303.6 & \\
\hline & 3 & 304 & 84 & 0.933 & 1.5 & 293.9 & \\
\hline & 4 & 304 & 6 & 1.037 & 0.2 & 323.3 & \\
\hline & 5 & 302 & 6 & 0.879 & 12.0 & 328.0 & \\
\hline & 6 & 303 & 10 & 0.917 & 1.9 & 326.7 & \multirow{2}{*}{ FTIR } \\
\hline & 7 & 303 & 81 & 0.846 & 7.8 & 301.0 & \\
\hline & 8 & 304 & 7 & 0.930 & 9.0 & 325.0 & \multirow{2}{*}{ FTIR with $\mathrm{NaCl}$ seeds } \\
\hline & 9 & 303 & 81 & 0.906 & 10.0 & 334.0 & \\
\hline & 10 & 304 & 9 & 0.914 & 10.6 & 386.5 & \multirow{2}{*}{ UV/Vis } \\
\hline & 11 & 304 & 80 & 0.910 & 7.7 & 364.1 & \\
\hline & 12 & 305 & 79 & 0.927 & 12.1 & 288.1 & LWC by FTIR \\
\hline & 13 & 305 & 79 & 0.918 & 10.6 & 294.7 & LWC by SMPS \\
\hline \multirow{16}{*}{ Isoprene } & 14 & 302 & 7 & 0.896 & 7.0 & 353.0 & \multirow{4}{*}{ size and yield } \\
\hline & 15 & 302 & 85 & 0.804 & 6.0 & 364.0 & \\
\hline & 16 & 301 & 7 & 0.850 & 0.0 & 311.7 & \\
\hline & 17 & 302 & 80 & 0.844 & 0.3 & 308.5 & \\
\hline & 18 & 303 & 7 & 0.901 & 0.0 & 299.5 & \multirow{4}{*}{ FTIR } \\
\hline & 19 & 303 & 81 & 0.799 & 0.3 & 270.2 & \\
\hline & 20 & 302 & 80 & 0.828 & 0.2 & 273.0 & \\
\hline & 21 & 301 & 8 & 0.790 & 0.0 & 283.1 & \\
\hline & 22 & 303 & 9 & 0.873 & 3.0 & 301.0 & \multirow{2}{*}{ FTIR with $\mathrm{NaCl}$ seeds } \\
\hline & 23 & 303 & 79 & 0.827 & 4.0 & 325.0 & \\
\hline & 24 & 303 & 8 & 0.823 & 0.1 & 332.5 & \multirow{2}{*}{ UV/Vis } \\
\hline & 25 & 303 & 81 & 0.877 & 0.3 & 363.0 & \\
\hline & 26 & 305 & 81 & 0.831 & 1.5 & 288.8 & LWC by FTIR \\
\hline & 27 & 304 & 78 & 0.823 & 0.5 & 313.5 & LWC by SMPS \\
\hline & 28 & 303 & 7 & 0.810 & 0.2 & 295.1 & \multirow{2}{*}{ ESI-HRMS } \\
\hline & 29 & 303 & 85 & 0.804 & 0.5 & 290.2 & \\
\hline
\end{tabular}

growth factor of SOA. Aklilu and Mozurkewich (2004) gave a GF range of 1.05-1.12 for atmospheric organic particles (79\% RH). Stroud et al. (2004) predicted a GF of 1.1 for the organic aerosols from toluene-NO-isopropyl nitrite irradiations at $79 \% \mathrm{RH}$. Prenni et al. (2007) reported the GF of $1.065 \pm 0.02$ at $85 \% \mathrm{RH}$ for SOA formed from toluene. Jimenez et al. (2009) obtained $\mathrm{GF}=1.057 \pm 0.02$ at $95 \%$ $\mathrm{RH}$ for SOA from isoprene. In general, our results of GF are in good agreement with previous estimates, indicating that the LWC measured by our modified SMPS is reliable.

\subsubsection{SOA yields}

We assumed that the VGF did not change during the reaction course. Thus, the LWC from toluene and isoprene under humid conditions can be determined by VGF. Figure 2 shows that in touene- $\mathrm{NO}_{2}$ irradiations, the mass concentrations of
SOA at $81 \% \mathrm{RH}$ are much larger than those at $10 \% \mathrm{RH}$, with a ratio of maximum mass concentration of SOA at $81 \%$ $\mathrm{RH}$ to that at $10 \%$ being 2.2. However, in isoprene- $\mathrm{NO}_{2}$ irradiations, the mass concentrations of SOA at $80 \% \mathrm{RH}$ are much lower than those at $7 \% \mathrm{RH}$, with the ratio of maximum mass concentration of SOA being 0.57 , which is almost the same as that from isoprene- $\mathrm{O}_{3}$ reactions (the ratio is 0.45 ). For isoprene- $\mathrm{H}_{2} \mathrm{O}_{2}$ irradiations, the mass concentrations of SOA from humid conditions are generally larger than those under dry conditions. Nevertheless, the maximum mass concentration of SOA from humid conditions is $177.9 \mu \mathrm{g} \mathrm{m}^{-3}$ (the ratio is 1.01), which is close to that from dry conditions.

The mass yield of SOA generally increases with time. The maximum yields during the experimental course were used for the following discussion. The mean maximum yields of SOA from toluene were obtained to be $5.58 \pm 0.76 \%$ (dry) 

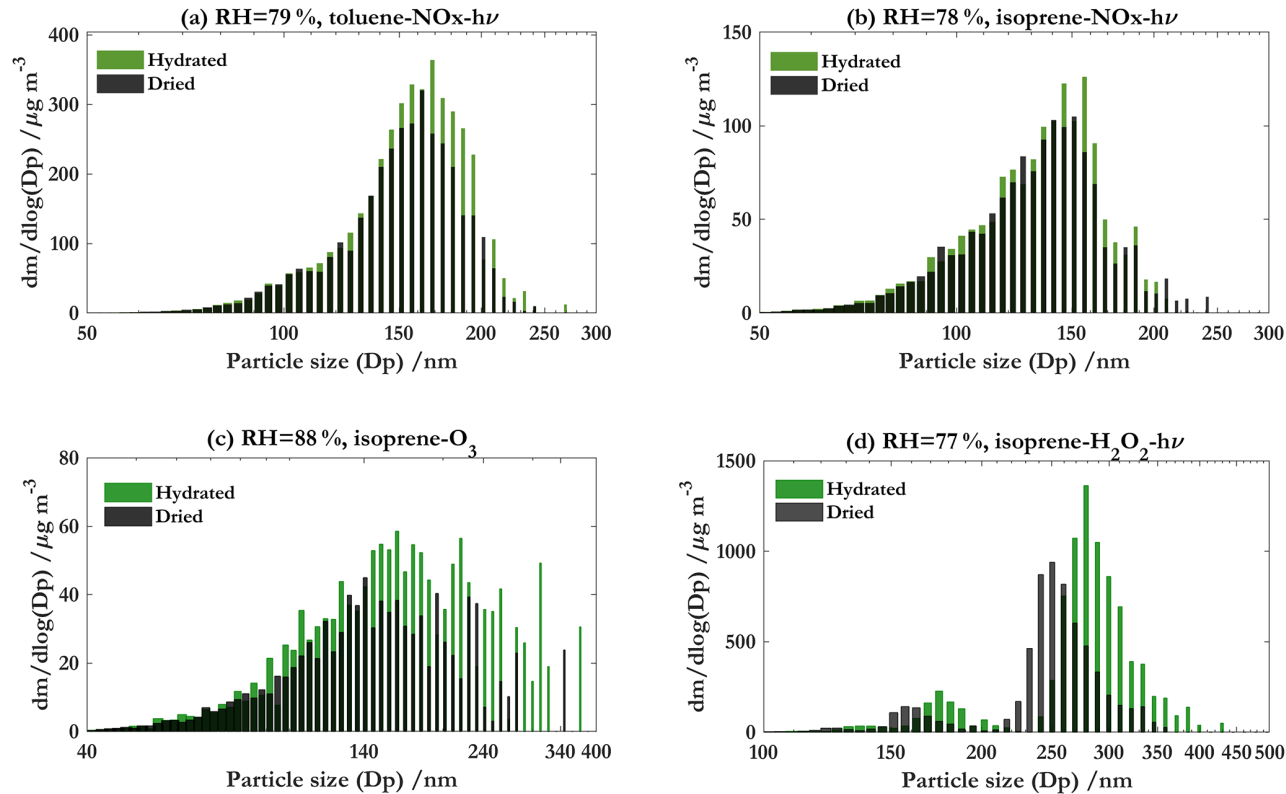

Figure 1. Mass concentration distributions of both dried and hydrated particles from both toluene and isoprene systems at $3 \mathrm{~h}$ after the initiation of reaction.

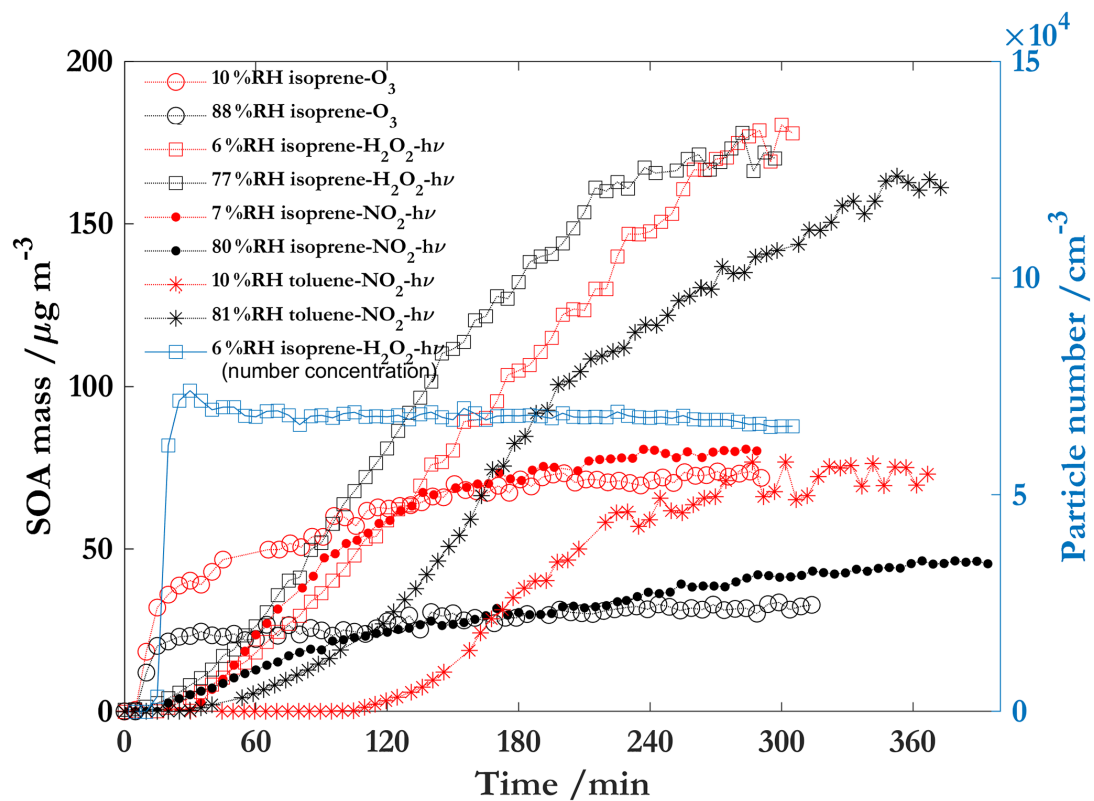

Figure 2. Mass concentration time profiles of SOA from different toluene and isoprene reaction systems under dry and humid conditions. An SOA density of $1.4 \mathrm{~g} \mathrm{~cm}^{-3}$ was used and applied to the SMPS mass correction (Dommen et al., 2006; Sato et al., 2007). The blue square markers are the number concentration of SOA from isoprene- $\mathrm{H}_{2} \mathrm{O}_{2}$ irradiations at $6 \% \mathrm{RH}$. The wall loss rate constant of particles was less dependent on RH conditions, so an average value of $4.8 \times 10^{-3} \mathrm{~min}^{-1}$ was used to correct the SOA formation.

and $8.97 \pm 0.84 \%$ (humid), respectively (Fig. 3). Our results are within the range obtained by other investigators (Kamens et al., 2011; Odum et al., 1997; Ng et al., 2007). Previous studies (Kamens et al., 2011; Zhou et al., 2011; Jia and Xu 2014; Wang et al., 2016) mainly ascribed the positive effect of RH on SOA yields from aromatics to LWC, which can en- hance the formation of SOA by aqueous reactions, such as reactive uptake of glyoxal in aerosol water. Our yields of SOA from toluene are smaller than those from $\mathrm{Ng}$ et al. (2007) (around $11 \%$ at $4 \%$ RH) and Hildebrandt et al. (2009) (11$17 \%$ at $21 \% \mathrm{RH}$ ), which is probably due to the additional and excessive $\mathrm{OH}$ radical sources ( $\mathrm{HONO}$ or $\mathrm{H}_{2} \mathrm{O}_{2}$ ) used in 


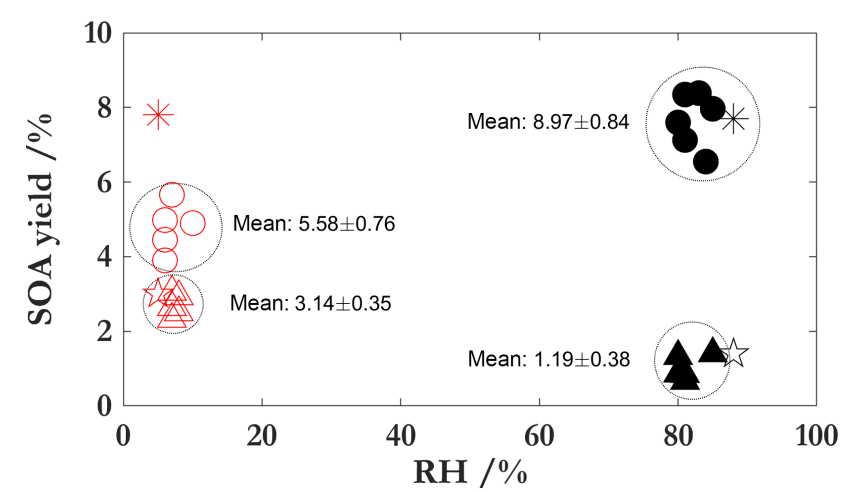

Figure 3. Maximum yields of SOA from toluene and isoprene under dry (red color) and humid (black color) conditions (o: toluene- $\mathrm{NO}_{2}$ $h v ; \triangle$ : isoprene- $\mathrm{NO}_{2}-h v ; \star$ : isoprene- $\mathrm{O}_{3} ; *$ : isoprene- $\left.\mathrm{H}_{2} \mathrm{O}_{2}-h v\right)$.

their experiments. In addition, the temperature in this study is higher than the previous studies, which may be another reason accounting for the lower SOA yields in this work.

A negative effect of RH on SOA yields was observed in the systems of isoprene- $\mathrm{NO}_{2}-h v$ and isoprene- $\mathrm{O}_{3}$. The mean maximum yields from isoprene- $\mathrm{NO}_{2}$ irradiations are reduced from $3.14 \pm 0.35 \%$ (dry) to $1.19 \pm 0.38 \%$ (humid) (Fig. 3). This negative RH effect is in good agreement with the corresponding results from Zhang et al. (2011) and Lewandowski et al. (2015). The yields of SOA from our isoprene- $\mathrm{O}_{3}$ reactions are $3.00 \%$ (dry) and $1.40 \%$ (humid), which are quite close to the results from the isoprene- $\mathrm{NO}_{2}$ system, while $\mathrm{RH}$ has a very weak effect on the SOA yields from isoprene$\mathrm{H}_{2} \mathrm{O}_{2}$ irradiations in our study. The maximum yields of $\mathrm{SOA}$ were determined to be $7.7 \%$ (dry) and $7.8 \%$ (humid) from photooxidation of isoprene- $\mathrm{H}_{2} \mathrm{O}_{2}$, which are in good agreement with the results (around $8 \%$ ) of isoprene- $\mathrm{H}_{2} \mathrm{O}_{2}$ irradiations under dry conditions from Clark et al. (2016). A similar yield (7\%) of SOA from photooxidation of isoprene$\mathrm{NO}_{x}-\mathrm{H}_{2} \mathrm{O}_{2}$ was also obtained in the results from Nguyen et al. (2011b). Based on the experimental conditions in Nguyen et al. (2011b), we estimated that for their reaction system over $99 \%$ of isoprene was oxidized by $\mathrm{OH}$ and the remaining $1 \%$ by $\mathrm{O}_{3}$ by using simulations based on the MCM. Thus, the reaction system by Nguyen et al. (2011b) can be considered to be closer to the isoprene- $\mathrm{H}_{2} \mathrm{O}_{2}$ system. In addition, some other previous studies (Gaston et al., 2014; Riedel et al., 2015; Zhang et al., 2018) showed that RH had a negative effect on the formation of SOA from isoprene-OH systems due to an acid dilution effect. In these studies, acidic sulfate seed particles were used and the acid-catalyzed effect was very obvious. Thus, higher RH can reduce the acidity of the seed particles by particle water. In our study acidic seed particles were from a little amount of $\mathrm{H}_{2} \mathrm{SO}_{4}$ formed from the gas-phase reaction of $\mathrm{SO}_{2}$ and $\mathrm{OH}$. It was estimated that the mass concentration of $\mathrm{H}_{2} \mathrm{SO}_{4}$ particles was less than $1 \mu \mathrm{g} \mathrm{m}^{-3}$. When liquid water content increased from
$1 \mu \mathrm{g} \mathrm{m}^{-3}$ to the maximum $54 \mu \mathrm{g} \mathrm{m}^{-3}$ under humid conditions, the $\mathrm{pH}$ value was estimated to be in the range of 2 to 3.7 , indicating that the $\mathrm{pH}$ variation was small in our experimental conditions. Therefore, compared with previous studies, the acid dilution effect was not remarkable in our work. These results show that high $\mathrm{RH}$ can reduce the maximum yields of SOA from the reaction channel of isoprene with $\mathrm{O}_{3}\left(\mathrm{O}_{3}\right.$ channel $)$ and that $\mathrm{RH}$ has little effect on the maximum yields from the reaction channel of isoprene with $\mathrm{OH}$ (OH channel) without sufficiently high mass concentrations of acid particles. Thus, it shows that the ozonolysis of isoprene is probably a key pathway influencing SOA formation in isoprene- $\mathrm{NO}_{2}$ irradiations in our experimental conditions, which will be further discussed in a later section.

In our isoprene- $\mathrm{NO}_{2}$ irradiations, based on the MCM simulation (Exp. 25), the amount of isoprene oxidized by $\mathrm{OH}$, $\mathrm{O}_{3}$, and $\mathrm{NO}_{3}$ is 59,25 , and $16 \%$ at the end of reactions, respectively. There are cross-reactions when $\mathrm{NO}_{2}$ and $\mathrm{O}_{3}$ are both present. Thus, we cannot deduce SOA contribution simply by initial ratios of isoprene oxidized by $\mathrm{OH}$ and $\mathrm{O}_{3}$. Since SOA is mainly formed by the secondary or later generation products, we can evaluate the contribution of reaction pathways to the formation of SOA in terms of SOA precursors from different channels. As described previously, SCIs can be taken as the SOA precursors from the $\mathrm{O}_{3}$ channel, while IEPOX, MPAN, HMML, and MAE can be used as SOA precursors from the $\mathrm{OH}$ channel. The MCM simulations show that the total yield of SCIs was dominant as compared to $\mathrm{OH}$ channel precursors such as IEPOX, MPAN, HMML, and MAE. The former accounts for $70 \%$ of total concentrations (ppb) of SOA precursors, and the latter (IEPOX + MPAN + HMML + MAE) $30 \%$ at the end of reaction in isoprene$\mathrm{NO}_{2}$ irradiations. Therefore, even though $59 \%$ of isoprene was consumed by $\mathrm{OH}$ and only $25 \%$ by $\mathrm{O}_{3}$, the formation of SOA in isoprene- $\mathrm{NO}_{2}$ was mainly from the $\mathrm{O}_{3}$ channel. For these three oxidation channels, RH has little effect on SOA yields from $\mathrm{OH}$ channel oxidization. Previous studies have shown that humidity has little effect on SOA formation from $\mathrm{NO}_{3}$ oxidation of alkenes (Bonn and Moorgat, 2002; Fry et al., 2009; Boyd et al., 2015). Thus, only the $\mathrm{O}_{3}$ channel is greatly influenced by RH. The maximum possibility is that the $\mathrm{O}_{3}$ channel can produce SCIs that can be consumed by water. Thus, although most of the isoprene was oxidized by $\mathrm{OH}$ and the SOA yield from the $\mathrm{OH}$ channel was over 2 (5) times greater than that from the $\mathrm{O}_{3}$ channel under dry (humid) conditions, the $\mathrm{O}_{3}$ channel was still a major pathway influenced by water vapor in the isoprene- $\mathrm{NO}_{2}$ system, which will be discussed in the following section.

\subsection{UV-Vis spectra of SOA}

The molecular sizes of SOA can reveal the degree of oligomerization reactions. Larger molecules displayed higher absorbance in longer wavelength regions as surmised by Mostafa et al. (2014). Thus, we used the UV-Vis spectra 

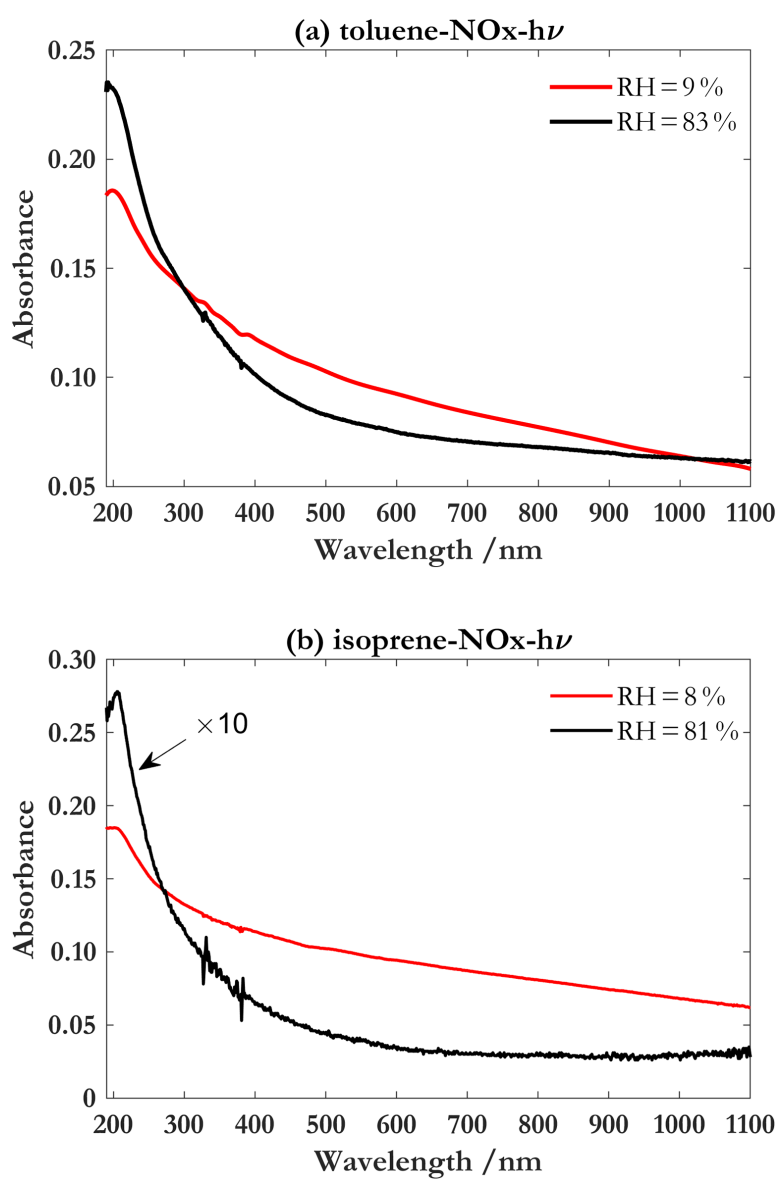

Figure 4. UV-Vis spectra of SOA from toluene (a) and isoprene (b) photooxidations under dry and humid conditions.

to determine the molecular size information of SOA, which can provide information about the oligomerization degree of molecular size through the ratio of E2 / E3 (absorbance at $250 \mathrm{~nm}$ divided by absorbance at $365 \mathrm{~nm}$ ) indirectly. Lower E2 / E3 ratios are associated with higher molecular weight (Peuravuori and Pihlaja, 1997; Duarte et al., 2005). All the spectra are characterized by a continuous absorption that increases with decreasing wavelength from $200 \mathrm{~nm}$ up to about $1100 \mathrm{~nm}$ (Fig. 4), which indicates the presence of conjugated double bond molecules (such as oligomers). The ratios of E2 / E3 are 1.27 (1.53), 1.29 (2.25), 1.69 (1.97), and 1.55 (1.73) under dry (humid) conditions from our systems of toluene- $\mathrm{NO}_{2}$, isoprene- $\mathrm{NO}_{2}$, isoprene- $\mathrm{O}_{3}$, and isoprene$\mathrm{H}_{2} \mathrm{O}_{2}$, respectively. The E2 / E3 ratios show that high $\mathrm{RH}$ can indeed reduce molecular sizes of SOA and suppress the oligomerization reactions. Zhang et al. (2011) and Nguyen et al. (2011b) both reported that oligomers were greatly reduced under humid conditions, and considered that high RH suppressed the oligomerization reactions with water as a product. Nevertheless, if the suppression of the oligomerization reactions under humid conditions is the main reason for the decrease in SOA yield from isoprene, why is the maximum

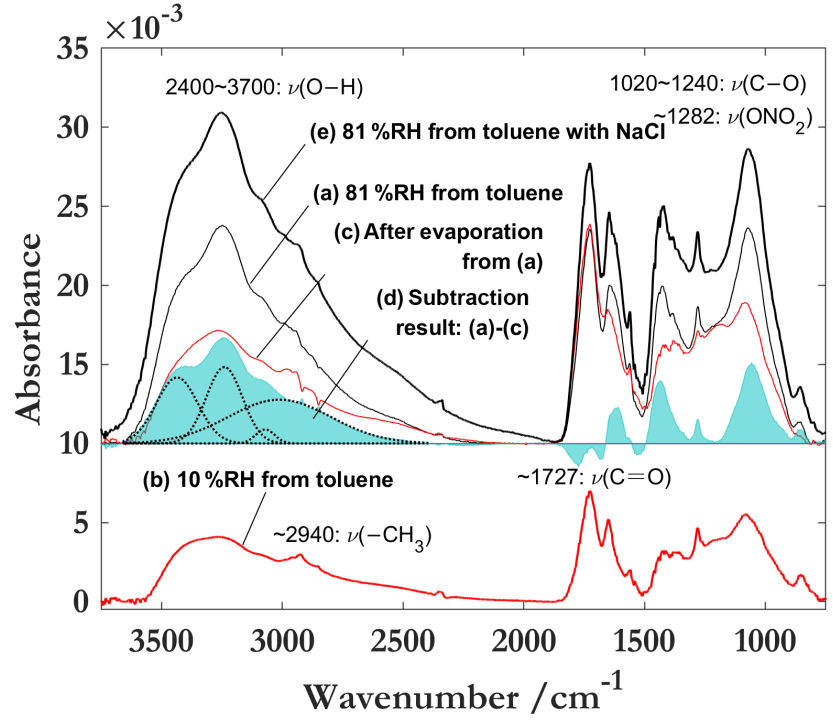

Figure 5. Infrared spectra of SOA from toluene irradiations under humid (a) and dry (b) conditions. The infrared spectrum of (c) was obtained after evaporation of SOA from (a) for $15 \mathrm{~min}$ at $110^{\circ} \mathrm{C}$; the difference spectrum between (a) and (c) is in the blue area (d); the infrared spectrum of (e) is with extra LWC by $\mathrm{NaCl}$ seeds. The main bands are the hydrogen bonded $\mathrm{O}-\mathrm{H}$ stretch in alcohols or acids $\left(2400-3700 \mathrm{~cm}^{-1}\right)$, the carbonyl $(\mathrm{C}=\mathrm{O})$ band at $1727 \mathrm{~cm}^{-1}$, the organonitrate $\left(\mathrm{ONO}_{2}\right)$ bands at 1636,1278 , and $855 \mathrm{~cm}^{-1}$, the $\mathrm{C}-\mathrm{OH}$ band at $1423 \mathrm{~cm}^{-1}$, and the $\mathrm{C}-\mathrm{OH}$ stretch at $1080 \mathrm{~cm}^{-1}$.

yield from isoprene- $\mathrm{H}_{2} \mathrm{O}_{2}$ irradiations unchanged under humid conditions? Besides the weak acid dilution effect in our experimental conditions, there must be an intrinsic mechanism regarding the influences of RH on the SOA yield from isoprene. In addition, oligomers have also been identified as important products of SOA from aromatics, and water is a byproduct during the oligomerization process (Kalberer et al., 2004; Lim et al., 2010; Gaston et al., 2014). However, a negative effect of RH on SOA yield from aromatics has never been observed. This is because there are likely competing processes that are responsible for SOA formation from aromatics under humid conditions. Oligomers are generally inhibited by higher RH, while the organics formed by aqueous reactions are enhanced.

\subsection{IR spectra of SOA}

\subsubsection{Toluene}

Figure 5a and $\mathrm{b}$ show the typical infrared spectra of SOA from the irradiations of toluene under both dry and humid conditions. The prominent features on SOA spectra are the board hydrogen bonded $\mathrm{O}-\mathrm{H}$ stretching, the carbonyl $\mathrm{C}=\mathrm{O}$ stretching, the organic nitrate $\left(\mathrm{ONO}_{2}\right)$ bands, the $\mathrm{C}-\mathrm{OH}$ bands of alcohols or polyalcohol. The bands all greatly increase by over 2 times as RH increases from 10 to $81 \%$. 
These changes in band strength with RH are quite similar to the changes in the SOA mass yield with RH.

To further reveal the chemical properties of the increased products formed from humid conditions, the SOA sample from humid conditions was evaporated. First, we found that the IR spectrum of SOA almost did not change after being heated at $100^{\circ} \mathrm{C}$ for $15 \mathrm{~min}$. Then the sample was further evaporated at $110^{\circ} \mathrm{C}$ for $15 \mathrm{~min}$. After the evaporation at $110^{\circ} \mathrm{C}$, the major absorption bands were considerably changed. As a result, the spectrum is almost the same as the spectrum of SOA collected under dry conditions (Fig. 5c). The major reduced absorptions are from the $\mathrm{O}-\mathrm{H}$ and $\mathrm{C}-\mathrm{OH}$ bands (Fig. 5d). These bands are assigned to hydrates of glyoxal and other water-soluble compounds in SOA (Volkamer et al., 2009; Lim et al., 2010; Kamens et al., 2011; Jia and $\mathrm{Xu}, 2014$; Wang et al., 2016). Therefore, alcohols (such as hydrates) are considered major contributors to toluene SOA under humid conditions.

LWC is an important factor that can greatly influence the contribution of SOA from aqueous reactions. The maximum LWC was measured to be about $44 \mu \mathrm{g} \mathrm{m}^{-3}$ from humid toleuene- $\mathrm{NO}_{2}$ irradiations. To determine the role of LWC in SOA formation, extra LWC was introduced into the reaction system by adding $10 \mu \mathrm{g} \mathrm{m}^{-3}$ of $\mathrm{NaCl}$ particles. The initial LWC was determined to be $30 \mu \mathrm{g} \mathrm{m}^{-3}$, and maximum LWC was $74 \mu \mathrm{g} \mathrm{m}^{-3}$ during $6 \mathrm{~h}$ of reaction. The SOA mass concentration was obtained by subtracting the mass concentrations of $\mathrm{NaCl}, \mathrm{NaNO}_{3}$, and $\mathrm{LWC}$ from total mass concentration of particles. Compared with the experiment without $\mathrm{NaCl}$, the SOA mass concentrations increased by $16 \%$ in the experiment with $\mathrm{NaCl}$, and all the bands assigned to $\mathrm{O}-\mathrm{H}, \mathrm{C}=\mathrm{O}$, and $\mathrm{C}-\mathrm{OH}$ were enhanced by 50,29 , and $35 \%$, respectively (Fig. 5e). This demonstrates that the increase in LWC can greatly enhance the formation of SOA from hydration of glyoxal. Therefore, it is concluded from our study that the formation of SOA from toluene is controlled by LWC under humid conditions, and that most SOA is formed by aqueous reactions in touene- $\mathrm{NO}_{2}$ irradiations.

\subsubsection{Isoprene}

\section{Isoprene- $\mathrm{NO}_{2}$ system}

The spectra of SOA from the irradiations of isoprene- $\mathrm{NO}_{2}$ are characterized by the high abundance of $\mathrm{C}=\mathrm{O}$ and $\mathrm{ONO}_{2}$ groups (Fig. 6). There are three bands assigned to different kinds of $\mathrm{C}-\mathrm{O}$ or $\mathrm{C}-\mathrm{O}-\mathrm{O}$ groups in the region of 927$1243 \mathrm{~cm}^{-1}$ under dry conditions (Pretsch et al., 2009). These bands are indicators of alcohols and polymeric structures (Czoschke et al., 2003). Thus, oligomers and organic nitrates are dominant species in SOA. Under humid conditions, the absorption intensities of the bands $\left(\mathrm{O}-\mathrm{H}, \mathrm{C}=\mathrm{O}, \mathrm{ONO}_{2}, \mathrm{C}-\right.$ $\mathrm{O}$, or $\mathrm{C}-\mathrm{O}-\mathrm{O}$ ) are all reduced by 2 times. The tert-nitrate can hydrolyze in particle water by the replacement of $\mathrm{ONO}_{2}$ with the -O-H group (Liu et al., 2012). Because such replacement

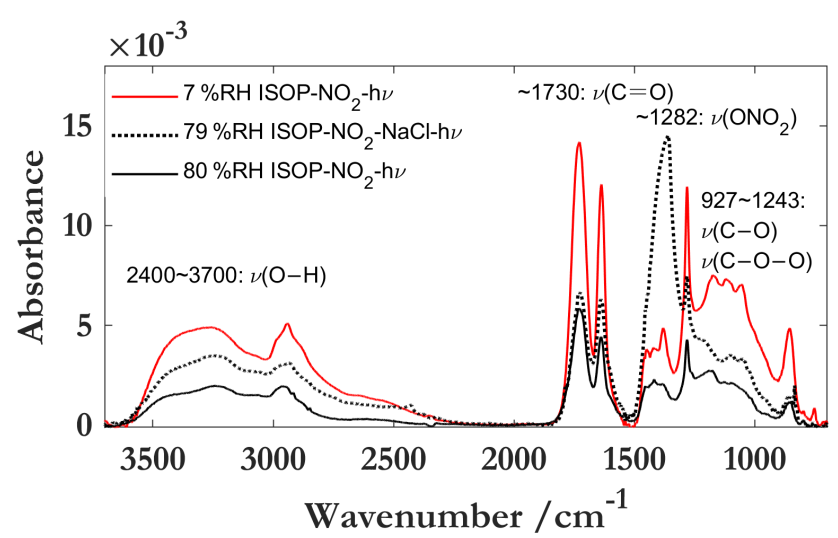

Figure 6. Infrared spectra of SOA from isoprene irradiations under dry and humid conditions. The bands at 1636,1282 , and $855 \mathrm{~cm}^{-1}$ are from $\mathrm{ONO}_{2}$. The bands at 1170 and $1121 \mathrm{~cm}^{-1}$ are assigned to $\mathrm{C}-\mathrm{O}-\mathrm{C}$ in oligomers or $\mathrm{C}-\mathrm{O}$ in carboxylic acids, and the band at $1055 \mathrm{~cm}^{-1}$ is from alcohols. The absorption shoulder from 927 to $1080 \mathrm{~cm}^{-1}$ is assigned to $\mathrm{C}-\mathrm{O}$ and $\mathrm{O}-\mathrm{O}$ in the peroxide group (C-O-O) (Pretsch et al., 2009).

hardly changes the vapor pressure of corresponding species (Pankow and Asher, 2008), newly formed alcohols should remain in the aerosol phase. We also did extra experiments to test the hydrolysis of organic nitrates. After the SOA sample from dry isoprene- $\mathrm{NO}_{2}$ irradiation was exposed to humid air $(90 \% \mathrm{RH})$ for $1 \mathrm{~h}$, we did not find any apparent change in the $\mathrm{ONO}_{2}$ group. Meanwhile, the peak height ratios of $\mathrm{ONO}_{2} / \mathrm{O}-\mathrm{H}$ from SOA are almost the same under dry and humid conditions. Thus, the hydrolysis of nitrates is not the major reason for the decrease in particle-phase organic nitrates. It also indicates that aerosol phase oligomers can hardly be influenced by RH. Then, high RH likely inhibited the formation of particle-phase organics by reducing the oligomerizations in the gas phase (e.g., SCI-derived oligomers).

RH generally enhances SOA formation by the aqueous reactions. Similarly, the aqueous reactions also exist in isoprene- $\mathrm{NO}_{2}$ irradiations. However, the maximum LWC from humid isoprene- $\mathrm{NO}_{2}$ irradiations was measured to be $8 \mu \mathrm{g} \mathrm{m}^{-3}$ at the end of reaction, which is much smaller as compared to $44 \mu \mathrm{g} \mathrm{m}^{-3}$ in toluene irradiations. Taking glyoxal as an example, although the maximum concentrations of glyoxal were simulated to be $39 \mathrm{ppb}$ in isoprene- $\mathrm{NO}_{2}$ irradiations, which is only $60 \%$ of its maximum concentration of $65 \mathrm{ppb}$ from toluene irradiations, due to the limitation of LWC, the SOA from the aqueous reactions was significantly reduced in isoprene- $\mathrm{NO}_{2}$ irradiations. To further confirm the role of LWC, we did an additional experiment with $\mathrm{NaCl}$ seeds (initial LWC of $30 \mu \mathrm{g} \mathrm{m}^{-3}$ ) in isoprene- $\mathrm{NO}_{2}$ irradiations. The results show that the absorptions of the bands from $\mathrm{O}-\mathrm{H}$ and $\mathrm{C}-\mathrm{OH}$ increase by 20 to $30 \%$ as compared to those without additional LWC (Fig. 6). It is true that increasing LWC can indeed enhance SOA formation in isoprene- $\mathrm{NO}_{2}$ 
irradiations; however, the absorptions of $\mathrm{C}=\mathrm{O}, \mathrm{ONO}_{2}$, and $\mathrm{C}-\mathrm{O}$ from dry conditions are still 2 times larger than those from the experiment with extra LWC. This demonstrates that the increase in SOA through aqueous reactions is far less than the decrease due to $\mathrm{H}_{2} \mathrm{O}$-related reactions under humid conditions. Thus, high water vapor can probably inhibit some key processes responsible for SOA formation from isoprene$\mathrm{NO}_{2}$ irradiations, which will be discussed in the following contents.

\section{Isoprene- $\mathrm{H}_{2} \mathrm{O}_{2}$ and isoprene- $\mathrm{O}_{3}$ systems}

To determine which process responds to the decrease in SOA under humid conditions from isoprene- $\mathrm{NO}_{2}$ irradiations, IR spectra of SOA from the $\mathrm{OH}$ and $\mathrm{O}_{3}$ channels were studied, respectively. Since isoprene is the chain unit of terpenes, the abundance of functional groups in oxidation products from isoprene and terpenes is expected to be close. O-Hcontaining products from terpene are 10 times more enriched from the $\mathrm{OH}$ channel oxidation than from the $\mathrm{O}_{3}$ one (Calogirou et al., 1999). Our extra experiments show the similar characteristics of IR spectra of SOA from both isoprene and $\alpha$-pinene (figure not shown). The peak height ratio of $\mathrm{O}-$ $\mathrm{H} / \mathrm{C}=\mathrm{O}$ is 0.24 in the SOA from the $\alpha$-pinene- $\mathrm{O}_{3}$ system, while it is as high as 2.19 in the SOA from the $\alpha$-pinene-OH system. Here the absorption ratio of $\mathrm{O}-\mathrm{H}$ to $\mathrm{C}=\mathrm{O}$ was used to examine the difference between the $\mathrm{O}_{3}$ and $\mathrm{OH}$ oxidation channels.

The IR spectra of SOA from the isoprene- $\mathrm{H}_{2} \mathrm{O}_{2}$ system are characterized by strong absorptions of both hydrogen bonded $\mathrm{O}-\mathrm{H}$ and $\mathrm{C}-\mathrm{OH}$ and by weak absorption of $\mathrm{C}=\mathrm{O}$ under both dry and humid conditions (Fig. 7, top), with the peak height ratios of $\mathrm{O}-\mathrm{H} / \mathrm{C}=\mathrm{O}$ being 1.63 (dry) and 1.45 (humid), which strongly supports the claim that alcohols or polyalcohols are major components of SOA from isoprene- $\mathrm{H}_{2} \mathrm{O}_{2}$ irradiations. Under humid conditions, the peak at $1090 \mathrm{~cm}^{-1}$ assigned to the $\mathrm{C}-\mathrm{O}-\mathrm{C}$ group from esters is slightly decreased, while the band at around $3200 \mathrm{~cm}^{-1}$ from $\mathrm{O}-\mathrm{H}$ absorption is broadened as compared to the dry condition. It indicates that esters (e.g., oligomers) decrease while the compounds containing $\mathrm{O}-\mathrm{H}$ increase under humid conditions. Nevertheless, the relative abundances of $\mathrm{O}-\mathrm{H}, \mathrm{C}=\mathrm{O}$, and $\mathrm{C}-\mathrm{OH}$ groups are almost the same between dry and humid conditions, which shows a weak effect of RH on SOA from isoprene$\mathrm{H}_{2} \mathrm{O}_{2}$ irradiations as compared to isoprene- $\mathrm{NO}_{2}$ irradiations. In the $\mathrm{OH}$ channel, isoprene can be oxidized to form $\mathrm{RO}_{2}$ $\left(\mathrm{ISOPO}_{2}\right)$. If there is no NO, $\mathrm{ISOPO}_{2}$ will be further oxidized to isoprene epoxydiols (IEPOX) by $\mathrm{OH}$ and $\mathrm{HO}_{2} \mathrm{rad}-$ icals. IEPOX are key intermediates of SOA in isoprene-OH reactions (Surratt et al., 2010). Under dry conditions, IEPOX can be adsorbed on $\mathrm{H}_{2} \mathrm{SO}_{4}$ seeds to form polyalcohols (e.g., 2-methyltetrols) through acid-catalyzed heterogeneous reactions, which can further form oligomers by esterification (Lin et al., 2012). Under humid conditions, IEPOX can be absorbed into particle water to produce polyalcohols (Nguyen

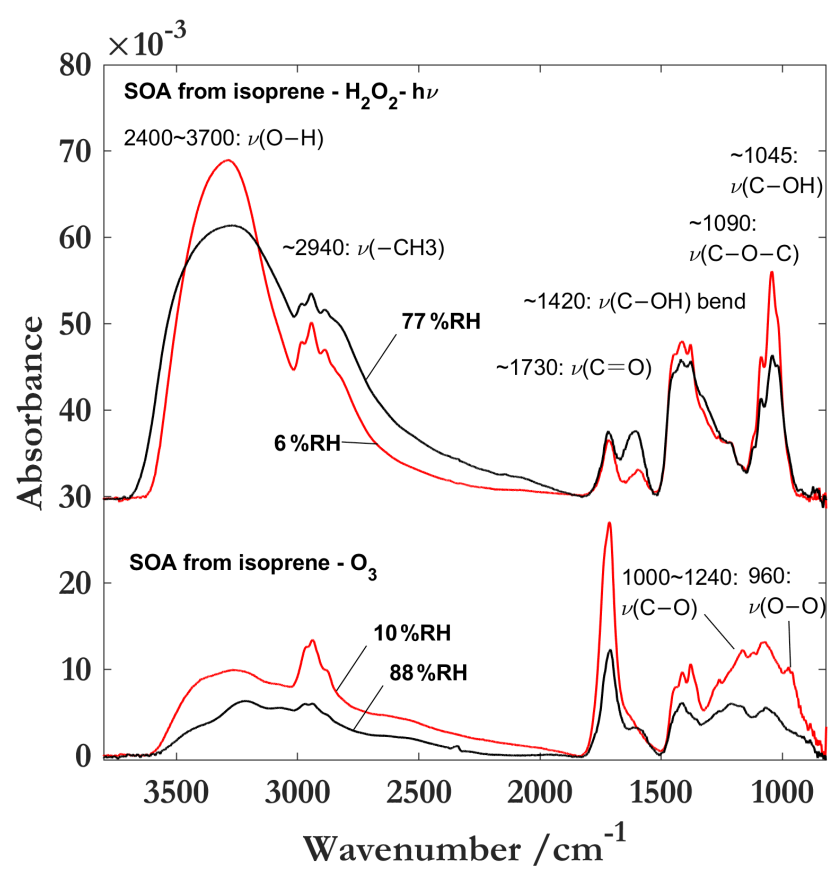

Figure 7. Infrared spectra of SOA from isoprene with different oxidants under dry and humid conditions. The bands at 1051 and $960 \mathrm{~cm}^{-1}$ are assigned to $\mathrm{C}-\mathrm{O}$ and $\mathrm{O}-\mathrm{O}$ groups in peroxide $\mathrm{O}-\mathrm{O}-$ O (Pretsch et al., 2009).

et al., 2014). In addition, the decrease in the $\mathrm{C}-\mathrm{O}-\mathrm{C}$ group indicates that the formation of oligomers is inhibited by the abundance of particle water as discussed in Sect. 3.2, which is in agreement with the result of Lin et al. (2014). Because polyalcohols (dominant) and IEPOX-derived oligomers are all in the aerosol phase, the total mass concentration of SOA does not change much under humid conditions in isoprene$\mathrm{H}_{2} \mathrm{O}_{2}$ irradiations. In other words, $\mathrm{RH}$ does not change the partition of IEPOX in our experimental conditions. This is consistent with the result of Riva et al. (2016) that water has a weaker impact on IEPOX-derived SOA yield.

In the isoprene- $\mathrm{O}_{3}$ systems, if the bands from $\mathrm{ONO}_{2}$ are excluded, both the shape and band intensities of IR spectra of SOA are quite similar to those of SOA from isoprene$\mathrm{NO}_{2}$ irradiations. All the bands assigned to $\mathrm{O}-\mathrm{H}, \mathrm{C}=\mathrm{O}$, and $\mathrm{C}-\mathrm{O}$ are reduced by over 2 times under humid conditions (bottom panel of Fig. 7). The ratios of $\mathrm{O}-\mathrm{H} / \mathrm{C}=\mathrm{O}$ are 0.36 (0.44) under dry (humid) conditions. The results are consistent with our expectation that lower ratios of $\mathrm{O}-\mathrm{H} / \mathrm{C}=\mathrm{O}$ should be in SOA from the ozonolysis of isoprene. Since $\mathrm{OH}$ radicals were well removed in our experiments, $\mathrm{SCIs}$ became the key intermediates of SOA. The $\mathrm{C}-\mathrm{O}-\mathrm{O}$ group is an indicator of the participation of SCIs in SOA from the ozonolysis of isoprene. The $\mathrm{C}-\mathrm{O}-\mathrm{O}$ group is very apparent under dry conditions, which decreases by $60 \%$ under humid condition. Oligomer products in SOA have been found to be formed by the reactions of $n(n=1-10)$ SCIs with $\mathrm{RO}_{2}$ in the ozonol- 
ysis of small enol ethers and trans-3-hexene (Sadezky et al., 2008; Zhao et al., 2015). Thus, SCI-derived oligomers are also deduced to be the key components in SOA from the $\mathrm{O}_{3}$ channel of isoprene. The model-simulated results show that when RH increases from 10 to $88 \%$, the consumption of SCIs by water increases from 13 to $58 \%$, while the SCIderived oligomers decrease from 87 to $42 \%$. The reaction products of SCIs with $\mathrm{H}_{2} \mathrm{O}$ have relatively high vapor pressures as compared to oligomers, so they are mainly in the gas phase. Therefore, humid conditions can reduce the SOA formed by SCI-related reactions in the isoprene- $\mathrm{O}_{3}$ systems.

In isoprene- $\mathrm{NO}_{2}$ irradiations, the ratios of $\mathrm{O}-\mathrm{H} / \mathrm{C}=\mathrm{O}$ are 0.35 (0.36) under dry (humid) conditions, which are almost the same as the corresponding values in isoprene- $\mathrm{O}_{3}$ but totally different from the values in isoprene- $\mathrm{H}_{2} \mathrm{O}_{2}$. The yields IR spectra (ratios of $\mathrm{O}-\mathrm{H} / \mathrm{C}=\mathrm{O}$ ) and the influence of $\mathrm{RH}$ on SOA production from the isoprene- $\mathrm{O}_{3}$ system is almost the same as those from isoprene- $\mathrm{NO}_{2}$ irradiations. In isoprene- $\mathrm{NO}_{2}$ irradiations, even though $60 \%$ of isoprene was oxidized by $\mathrm{OH}$, because of the presence of $\mathrm{NO}$, most of the $\mathrm{ISOPO}_{2}$ from oxidation of $\mathrm{OH}$ could be quickly consumed by NO to form MPAN (around $15 \mathrm{ppb}$ under both dry and humid conditions) and other products, leading to the decrease in IEPOX from $224.0 \mathrm{ppb}$ (in isoprene- $\mathrm{H}_{2} \mathrm{O}_{2}$ ) to $41.2 \mathrm{ppb}$ (in isoprene- $\mathrm{NO}_{2}$ ). The yield of MACR is generally greater in isoprene- $\mathrm{NO}_{2}$ irradiations and isoprene- $\mathrm{O}_{3}$ systems than that in isoprene- $\mathrm{H}_{2} \mathrm{O}_{2}$ irradiations. MACR can react to form MPAN in the presence of $\mathrm{NO}_{2}$, which can be oxidized by $\mathrm{OH}$ to form SOA precursors of epoxides (e.g., HMML, MAE), such as in the Nguyen et al. (2011b) work. Epoxides can further be oxidized to produce 2-MG and related oligomers (Surratt et al., 2010; Lin et al., 2013; Nguyen et al., 2015). 2-MG-derived oligomers can be enhanced under lower RH (Zhang et al., 2011). Both the results from Nguyen et al. (2014) and MCM simulations further show that if there are enough $\mathrm{OH}$ radicals, most MPAN can be further oxidized by $\mathrm{OH}$ to produce epoxides. However, since there were no extra $\mathrm{OH}$ sources in our systems, MCM simulations show that only $12 \%$ (24\%) of MPAN under dry (humid) conditions was oxidized by $\mathrm{OH}$ to produce HMML and MAE. The maximum concentrations of HMML and MAE were only 6.8 and $2.7 \mathrm{ppb}$ under dry conditions (Fig. 13), which is too small to explain the yields of SOA in isoprene$\mathrm{NO}_{2}$ irradiations. If we simply assume that the concentrations of SOA were proportional to the IEPOX concentration as in isoprene- $\mathrm{H}_{2} \mathrm{O}_{2}$ irradiations, over $70 \%$ of SOA should come from IEPOX in dry or humid isoprene- $\mathrm{NO}_{2}$ irradiations. However, the IR spectra of SOA from dry or humid isoprene- $\mathrm{NO}_{2}$ are totally different from those in isoprene$\mathrm{H}_{2} \mathrm{O}_{2}$ irradiations. In contrast, they are similar to those from the isoprene- $\mathrm{O}_{3}$ system. Thus, IEPOX is not the major contributor to $\mathrm{SOA}$ in isoprene- $\mathrm{NO}_{2}$ systems. On the other hand, similar to the isoprene- $\mathrm{O}_{3}$ system, SCI-related reactions in the isoprene- $\mathrm{NO}_{2}$ system were probably key pathways.

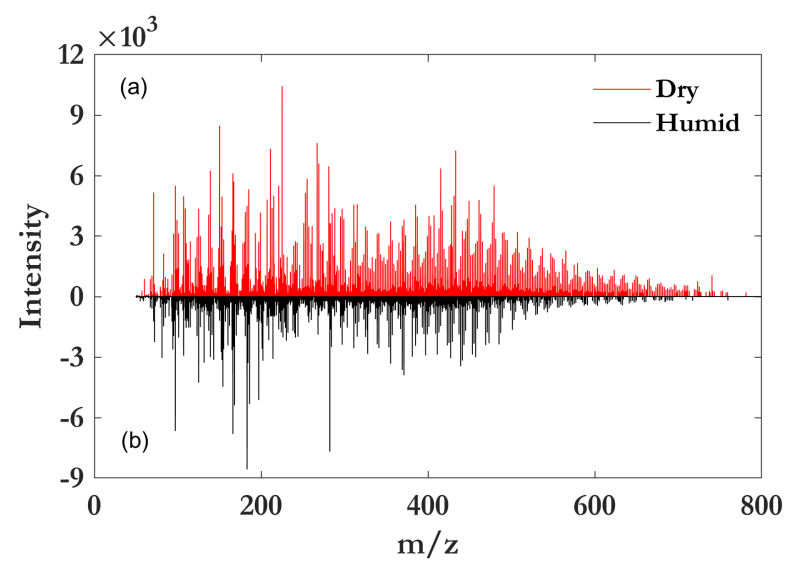

Figure 8. Positive ion mode ESI-Orbitrap mass spectra of SOA from isoprene- $\mathrm{NO}_{2}$ irradiations under dry (a) and humid (b) conditions.

\subsection{Mass spectra of isoprene SOA}

To further determine whether SCI-derived oligomers are the major components of SOA from isoprene- $\mathrm{NO}_{2}$ irradiations, the high-resolution mass spectra of SOA under dry and humid conditions were obtained with ESI-HRMS (Fig. 8). The mean molecular size of SOA was reduced from 352 under dry conditions to 295 under humid conditions, which is in good agreement with the results by UV/Vis spectra. The peaks on the spectrum show highly regular mass differences, especially in the range of $300 \sim 800 \mathrm{~m} / \mathrm{z}$, which is a typical structure for polymers or oligomers (Kalberer et al., 2004). The total intensity of peaks in the range of 300 to $800 \mathrm{~m} / \mathrm{z}$ under humid conditions is reduced by $75 \%$ as compared to that under dry conditions. This demonstrates that oligomers are probably a major component of SOA from isoprene- $\mathrm{NO}_{2}$ irradiations, which are greatly reduced under humid conditions. The mass spectrum of SOA from the ozonolysis of isoprene is similar to the one from the isoprene- $\mathrm{NO}_{2}$ system. The spectrum of SOA from isoprene- $\mathrm{H}_{2} \mathrm{O}_{2}$ (Fig. 9) shows a very different feature from that of the SOA from isoprene$\mathrm{NO}_{2}$. It does not reveal obviously regular structures of the peaks for oligomers.

To further characterize whether SCIs are the major building blocks of the oligomers in SOA from isoprene- $\mathrm{NO}_{2}$ irradiations, a Kendrick mass defect (KMD) analysis was used. The KMD analysis is a standard method to visualize the complex organic mass spectra (Kendrick, 1963). The Kendrick mass (KM) is converted from the IUPAC mass $M$ by multiplying a factor of $\mathrm{NM}_{\text {base }} / M_{\text {base }}$ (i.e., the factor is $14.00000 / 14.01565$ for the base unit of $\mathrm{CH}_{2}$ ) using Eq. (2). $\mathrm{NM}_{\text {base }}$ is the exact mass $M_{\text {base }}$ rounded to the nearest integer. KMD is calculated as the difference between the nominal $\mathrm{KM}$ (NKM) and KM using Eq. (3). The basic principle of the KMD method is that a homologous series of compounds differing only by a number of base units have identical KMD 


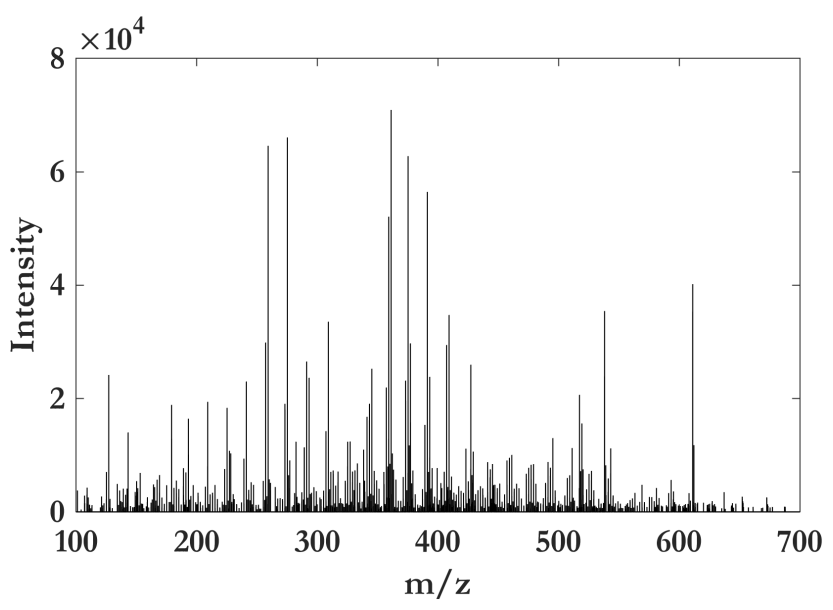

Figure 9. Positive ion mode ESI-Orbitrap mass spectra of SOA from isoprene- $\mathrm{H}_{2} \mathrm{O}_{2}$ irradiations under dry conditions.

values. Thus, the KMD analysis allows for the rapid identification oligomers by a plot of KMD vs. KM, in which homologous compounds can line up in the horizontal direction. Since the KMD analysis has a great advantage to clearly determine the molecular composition of hundreds of individual compounds in SOA samples, it has been applied extensively for complex SOA sample analyses using HR-MS (Reinhardt et al., 2007; Walser et al., 2008; Nguyen et al., 2010, 2011a; Nizkorodov et al., 2011). In addition, since different series of homologous oligomers may have similar KMD values, the KMD data need to be pre-sorted by the $z^{*}$ value which is calculated by Eq. (4) (Hsu et al., 1992).

$\mathrm{KM}=M \times \frac{\mathrm{NM}_{\text {base }}}{M_{\text {base }}}$

$\mathrm{KMD}=\mathrm{NKM}-\mathrm{KM}$

$z^{*}=\operatorname{modulo}\left(\frac{\mathrm{NM}}{\mathrm{NM}_{\mathrm{base}}}\right)-\mathrm{NM}_{\text {base }}$

\subsubsection{Base units of oligomers: SCIs}

There are 16 kinds of SCIs produced in isoprene- $\mathrm{NO}_{2}$ irradiations based on MCM v3.3.1 simulation, in which $\mathrm{CH}_{2} \mathrm{OO}$ $\left(\mathrm{CH}_{2} \mathrm{O}_{2}\right.$, with a yield of $\left.50.1 \%\right)$, MACROO $\left(\mathrm{C}_{4} \mathrm{H}_{6} \mathrm{O}_{2}\right.$, $18.3 \%)$, MVKOO $\left(\mathrm{C}_{4} \mathrm{H}_{6} \mathrm{O}_{2}, 12.2 \%\right)$, MGLOO $\left(\mathrm{C}_{3} \mathrm{H}_{4} \mathrm{O}_{3}\right.$, $11.3 \%)$, and GLYOO $\left(\mathrm{C}_{2} \mathrm{H}_{2} \mathrm{O}_{3}, 2.6 \%\right)$ account for $95 \%$ of total SCIs. To explain that these SCIs exist in SOA as base units of $\mathrm{CH}_{2} \mathrm{O}_{2}, \mathrm{C}_{4} \mathrm{H}_{6} \mathrm{O}_{2}, \mathrm{C}_{3} \mathrm{H}_{4} \mathrm{O}_{3}$, and $\mathrm{C}_{2} \mathrm{H}_{2} \mathrm{O}_{3}$, a wide set of other base units $\left(\mathrm{OH}, \mathrm{CO}, \mathrm{NO}_{2}, \mathrm{ONO}_{2}, \mathrm{CH}_{2}\right.$, $\mathrm{CH}_{2} \mathrm{O}$, and $\mathrm{COO}$ ) are also included for KMD analysis. The ratio of oligomers with a given base unit to total mass is defined to characterize the contribution of different base units to SOA. It should be pointed out that large uncertainties exist in the estimate of relative contributions of different units because of the poor quantification performance using ESI-MS

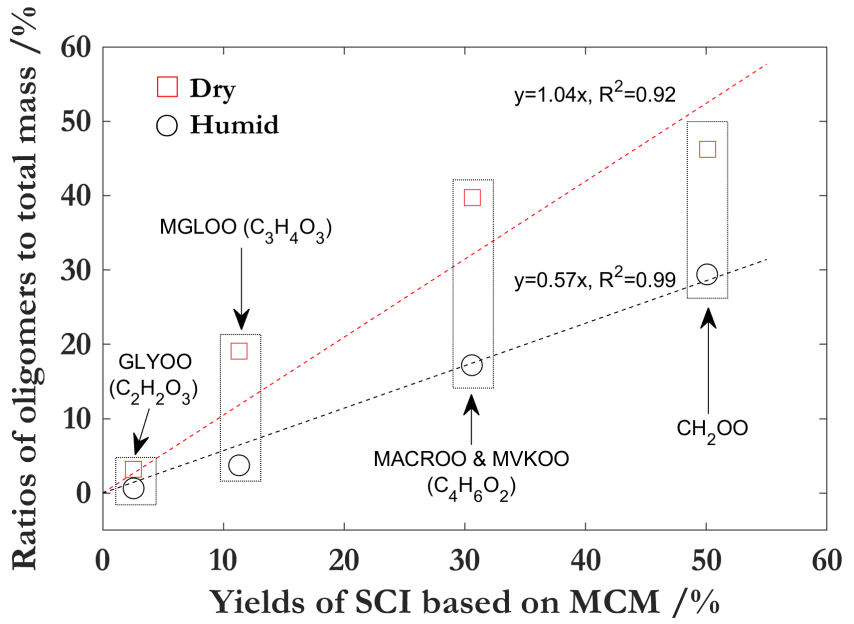

Figure 10. The correlation of yields of the top five SCIs $\left(\mathrm{CH}_{2} \mathrm{OO}\right.$, MACROO and MVKOO, MGLOO, and GLYOO) and the ratios of $\mathrm{CH}_{2} \mathrm{O}_{2}, \mathrm{C}_{4} \mathrm{H}_{6} \mathrm{O}_{2}, \mathrm{C}_{3} \mathrm{H}_{4} \mathrm{O}_{3}$, and $\mathrm{C}_{2} \mathrm{H}_{2} \mathrm{O}_{3}$ based oligomers to total mass under dry and humid conditions from isoprene- $\mathrm{NO}_{2}$ irradiations. Only the oligomers that belong to families (M- $[\mathrm{SCI}]_{n}$, $n=0,1,2,3 \ldots$ ) with $n \geq 2$ were taken into consideration.

techniques. Due to the cross containing of units in oligomer molecules, the sum of the ratios is larger than $100 \%$. The oligomers with the same base unit ( $M$-[base unit $]_{n}, n=$ $0,1,2,3 \ldots)$ that contains at least three compounds are considered one class of oligomers. The results show that only the ratios of oligomers with the base units of $\mathrm{CH}_{2} \mathrm{O}_{2}, \mathrm{C}_{4} \mathrm{H}_{6} \mathrm{O}_{2}$, $\mathrm{C}_{3} \mathrm{H}_{4} \mathrm{O}_{3}$, and $\mathrm{C}_{2} \mathrm{H}_{2} \mathrm{O}_{3}$ are proportional to the yields of corresponding SCIs from the isoprene- $\mathrm{NO}_{2}$ system. Figure 10 displays the correlation diagram between the ratios of oligomers (with $\mathrm{CH}_{2} \mathrm{O}_{2}, \mathrm{C}_{4} \mathrm{H}_{6} \mathrm{O}_{2}, \mathrm{C}_{3} \mathrm{H}_{4} \mathrm{O}_{3}$, and $\mathrm{C}_{2} \mathrm{H}_{2} \mathrm{O}_{3}$ as repeating units) to total mass and the top five SCI yields $\left(\mathrm{CH}_{2} \mathrm{OO}\right.$, MACROO, MVKOO, MGLOO, and GLYOO). It shows that the ratios linearly increase with increasing yields under both dry and humid conditions. Thus, this demonstrates that the oligomers with $\mathrm{CH}_{2} \mathrm{O}_{2}, \mathrm{C}_{4} \mathrm{H}_{6} \mathrm{O}_{2}, \mathrm{C}_{3} \mathrm{H}_{4} \mathrm{O}_{3}$, and $\mathrm{C}_{2} \mathrm{H}_{2} \mathrm{O}_{3}$ repeat units are from contributions of these SCIs of $\mathrm{CH}_{2} \mathrm{OO}$, MACROO (and MVKOO), MGLOO, and GLYOO in the isoprene- $\mathrm{NO}_{2}$ system. Therefore, these five SCIs are chosen as the base units for KMD analysis, which shows that the ratios of compounds containing SCI units are reduced by $45 \%$ on average as RH increases from 7 to $85 \%$. This is also in good agreement with MCM simulation of decrease in SCIderived oligomers by $44 \%$ and with the decrease in intensity of peroxide $\mathrm{C}-\mathrm{O}-\mathrm{O}$ absorption in FTIR (Fig. 6). In addition, the KMD analysis is also used to determine the components of oligomers in SOA from isoprene- $\mathrm{H}_{2} \mathrm{O}_{2}$. All the above base units are tested, and the results show that $\mathrm{CH}_{2} \mathrm{O}$ containing oligomers are the major products in SOA, and the chain lengths of oligomers are much shorter than those from isoprene- $\mathrm{NO}_{2}$. The maximum repeat unit number of $\mathrm{n}$ is less than 3 in most families of oligomers in SOA from isoprene- 
(a)
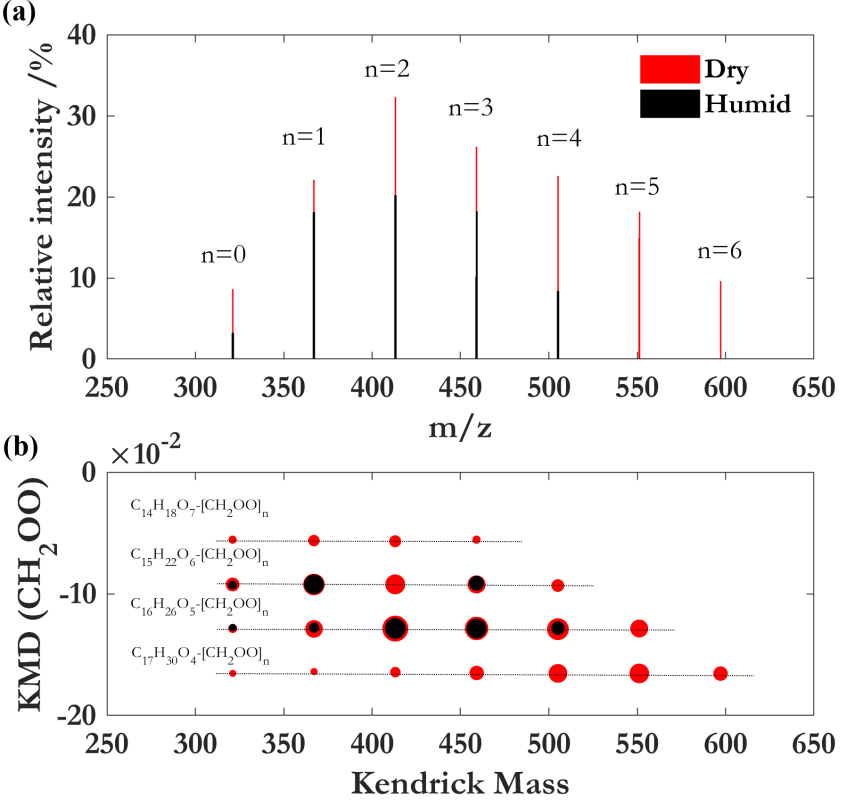

Figure 11. Positive mode mass spectra of oligomers with $\mathrm{CH}_{2} \mathrm{OO}$ as chain units in SOA from isoprene- $\mathrm{NO}_{2}$ irritations under dry and humid conditions (a) and corresponding plots of $\mathrm{KMD}\left(\mathrm{CH}_{2} \mathrm{OO}\right)$ vs. nominal $\mathrm{KM}\left(\mathrm{CH}_{2} \mathrm{OO}\right)(\mathbf{b})$. The horizontal lines connect the family of compounds with an equal elemental composition differing only by $\left[\mathrm{CH}_{2} \mathrm{OO}\right]_{n}(n=0,1,2,3 \ldots)$ groups.

$\mathrm{H}_{2} \mathrm{O}_{2}$. By contrast, the maximum value of $\mathrm{n}$ is larger than 5 in oligomer families of $\mathrm{SOA}$ from isoprene- $\mathrm{NO}_{2}$. This indicates that SCIs incline to produce long chain oligomers.

\subsubsection{Base unit of $\mathrm{CH}_{2} \mathrm{OO}$}

It has been considered that the $\mathrm{CH}_{2} \mathrm{OO}$ radical can serve as an oligomer unit in SOA from the ozonolysis of ethylene (Sakamoto et al., 2013). $\mathrm{CH}_{2} \mathrm{OO}$ has the highest yield $(50.1 \%)$ of all the SCIs from isoprene. The KMD analysis shows that the masses of $\mathrm{CH}_{2} \mathrm{OO}$-containing oligomers account for $46.2 \%$ (29.4\%) of the total mass on the MS under dry (humid) conditions. Figure 11 displays the selected mass spectra of oligomers with $\mathrm{CH}_{2} \mathrm{OO}$ as chain units and their corresponding KMD plots under dry and humid conditions, which shows that both the length of oligomer chains and the number of oligomers are greatly reduced under humid conditions. The number of oligomers under humid conditions is reduced by $64 \%$ as compared to dry conditions. Another feature of $\mathrm{CH}_{2} \mathrm{OO}$-based oligomers is that the sizes of their end groups are larger than 300 (C14-C17), which probably come from other oligomers formed during reactions. This indicates that most $\mathrm{CH}_{2} \mathrm{OO}$-based oligomers are formed in the particle phase.
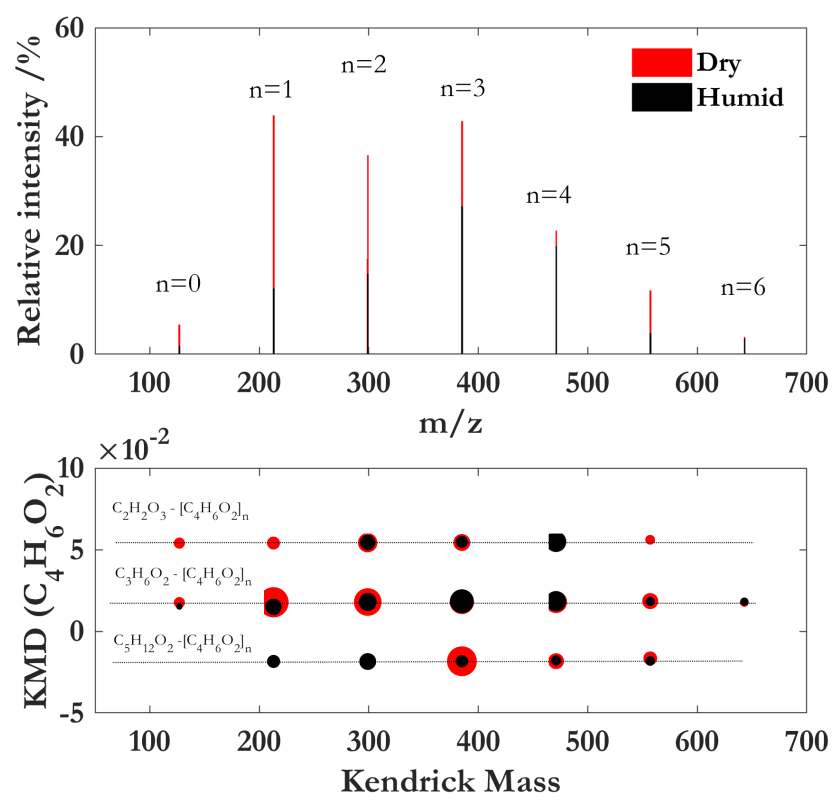

Figure 12. Mass spectra of oligomers with $\mathrm{C}_{4} \mathrm{H}_{6} \mathrm{O}_{2}$ (MACROO and $\mathrm{MVKOO}$ ) as the repeating unit and their Kendrick plots using $\mathrm{C}_{4} \mathrm{H}_{6} \mathrm{O}_{2}$ as the Kendrick base. Species separated by $\mathrm{C}_{4} \mathrm{H}_{6} \mathrm{O}_{2}$ groups fall on the horizontal lines.

\subsubsection{Base units of MACROO and MVKOO}

Figure 12 shows the mass spectra and KMD plot of oligomers with $\mathrm{C}_{4} \mathrm{H}_{6} \mathrm{O}_{2}$ (MACROO and MVKOO) as base units. The KMD analysis results show that the ratio of $\mathrm{C}_{4} \mathrm{H}_{6} \mathrm{O}_{2}$-based oligomers to total compounds is $39.7 \%$ $(17.2 \%)$ under dry (humid) conditions. In addition to $\mathrm{CH}_{2} \mathrm{OO}$, MACROO and MVKOO based oligomers have the second highest contribution to SOA among all the SCIs. Similar to $\mathrm{CH}_{2} \mathrm{OO}$, the maximum number of chain units is 6 in oligomers from $\mathrm{C}_{4} \mathrm{H}_{6} \mathrm{O}_{2}$. However, the size of end groups is much smaller than that from $\mathrm{CH}_{2} \mathrm{OO}$. The most frequent end group is $\mathrm{C}_{3} \mathrm{H}_{6} \mathrm{O}_{2}$ as shown in Fig. 12. Based on the Chemspider database and $\mathrm{MCM}$ simulation, we deduced that $\mathrm{C}_{3} \mathrm{H}_{6} \mathrm{O}_{2}$ is from hydroxyacetone (ACETOL), which is the most abundant carbonyl-containing products in the isoprene- $\mathrm{NO}_{2}$ reaction system. The maximum concentration of ACETOL is over $90 \mathrm{ppb}$ based on our experimental conditions. $\mathrm{C}_{2} \mathrm{H}_{2} \mathrm{O}_{3}$ is deduced to be glyoxylic acid that is one of products from isoprene irradiation. SCIs can react with carbonyl and alcohol products (e.g., ACETOL), $\mathrm{RO}_{2}$, and $\mathrm{H}_{2} \mathrm{O}$ (Calvert et al., 2000; Chao et al., 2015; Tobias and Ziemann, 2001). However, different from the isoprene- $\mathrm{O}_{3}$ system, MCM simulations show that most $\mathrm{RO}_{2}$ is consumed by $\mathrm{NO}$ in isoprene$\mathrm{NO}_{2}$ irradiations. Thus carbonyl and alcohol products become the major initiators of SCI oligomerizations.

An addition of a $\mathrm{C}-\mathrm{O}-\mathrm{O}$ group can change the vapor pressure of oligomers (containing $n$ SCI units) by a factor of $2.5 \times 10^{-3}$ (Pankow and Asher, 2008). The vapor pressures 
Table 2. List of major base units and their corresponding ratios of oligomers to total mass from SOA in isoprene- $\mathrm{NO}_{2}$ irradiations.

\begin{tabular}{llrrrr}
\hline Base unit & Unit name & SCI yields by MCM & \multicolumn{3}{c}{ Ratio of oligomers to total mass } \\
\cline { 4 - 6 } & & & Dry/\% & Humid/\% & Delta/\% \\
\hline $\mathrm{CH}_{2} \mathrm{O}_{2}$ & $\mathrm{CH}_{2} \mathrm{OO}$ & 50.1 & 46.2 & 29.4 & 36.3 \\
$\mathrm{C}_{4} \mathrm{H}_{6} \mathrm{O}_{2}$ & MACROO and MVKOO & 30.6 & 39.7 & 17.2 & 56.7 \\
$\mathrm{C}_{3} \mathrm{H}_{4} \mathrm{O}_{3}$ & MGLOO & 11.3 & 19.1 & 3.7 & 80.4 \\
$\mathrm{C}_{2} \mathrm{H}_{2} \mathrm{O}_{3}$ & GLYOO & 2.6 & 3.2 & 0.6 & 80.1 \\
\hline $\mathrm{C}_{4} \mathrm{H}_{6} \mathrm{O}_{3}$ & dehydrated 2-MG (or $\left.\mathrm{CH}_{3} \mathrm{OC}_{3} \mathrm{H}_{3} \mathrm{OO}\right)$ & $(1.4)$ & 25.3 & 9.0 & 64.6 \\
$\mathrm{CH}_{2}$ & - & - & 76.4 & 62.7 & 17.9 \\
$\mathrm{CH}_{2} \mathrm{O}$ & - & - & 78.5 & 67.6 & 13.8 \\
\hline
\end{tabular}

of SCI-derived oligomers (e.g., $\mathrm{C}_{3} \mathrm{H}_{3} \mathrm{O}_{2}-\left[\mathrm{C}_{4} \mathrm{H}_{6} \mathrm{OO}\right]_{n}$ ) are estimated to be less than $10^{-7} \mathrm{~atm}(n \geq 2)$ and $10^{-12} \mathrm{~atm}$ $(n \geq 4)$. The compounds can self-nucleate as their vapor pressures are less than $10^{-9} \mathrm{~atm}$ (Kamens et al., 1999). It indicates that the initial particles in the $\mathrm{O}_{3}$ oxidation channel of isoprene are formed by the self-nucleation of oligomers $(n \geq 4)$. The oligomers with $n \geq 2$ probably further condensed on these particles. Thus, MACROO- or MVKOObased oligomers can be formed in the gas phase (e.g., Reactions R1 and R2). With the increase in chain units, these oligomers can either self-nucleate or further oligomerize in the aerosol phase.

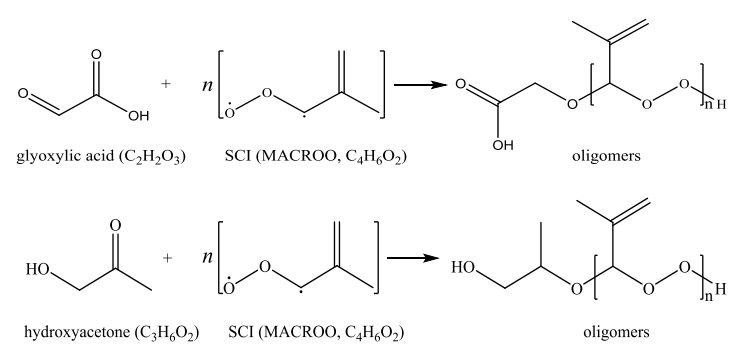

\subsubsection{Other base units of oligomers}

It is worth noticing that the yield of $\mathrm{CH}_{3} \mathrm{OC}_{3} \mathrm{H}_{3} \mathrm{OO}$ $\left(\mathrm{C}_{4} \mathrm{H}_{6} \mathrm{O}_{3}\right)$ is only $1.4 \%$ based on the MCM simulation. However, the contribution of $\mathrm{C}_{4} \mathrm{H}_{6} \mathrm{O}_{3}$ to oligomers is as high as $25.3 \%(9.0 \%)$ under dry (humid) conditions (Table 2). Thus, $\mathrm{C}_{4} \mathrm{H}_{6} \mathrm{O}_{3}$ is not totally from $\mathrm{CH}_{3} \mathrm{OC}_{3} \mathrm{H}_{3} \mathrm{OO}$. 2-MG usually serves as molecular tracers for isoprene SOA (Kleindienst et al., 2007). As reported by Zhang et al. (2011) and Nguyen et al. (2011b), $\mathrm{C}_{4} \mathrm{H}_{6} \mathrm{O}_{3}$ was the repeated unit of 2-MG's corresponding oligomers in $\mathrm{SOA}$ from isoprene- $\mathrm{NO}_{x}$ irradiations. Lin et al. (2013) reported that $\mathrm{C}_{4} \mathrm{H}_{6} \mathrm{O}_{3}$ was from MAE in MACR-NO $\mathrm{O}_{x}$ irradiations. Thus, $\mathrm{C}_{4} \mathrm{H}_{6} \mathrm{O}_{3}$ is probably formed from dehydration of 2-MG and MAE in oligomers. Considering the low yield of MAE in our system, we considered that most $\mathrm{C}_{4} \mathrm{H}_{6} \mathrm{O}_{3}$-based oligomers are probably contributed by 2-MG in our work. The ratios of $\mathrm{CH}_{2} \mathrm{OO}$, MACROO, and MVKOO based oligomers are almost 2 times larger than that from 2-MG under both dry and humid conditions. Thus, even though the ratio of $\mathrm{C}_{4} \mathrm{H}_{6} \mathrm{O}_{3}$-based oligomers was de- creased by $65 \%$ as RH increased from 7 to $85 \%, 2-\mathrm{MG}$ derived oligomers would not be the major reason for the decrease in SOA yield from isoprene- $\mathrm{NO}_{2}$ irradiations. In addition to $\mathrm{C}_{4} \mathrm{H}_{6} \mathrm{O}_{3}, \mathrm{CH}_{2}$ and $\mathrm{CH}_{2} \mathrm{O}$ based oligomeric compounds also have high ratios in isoprene- $\mathrm{NO}_{2}$ systems, which have been also reported as the most prominent units in SOA products from the ozonolysis of isoprene in the Nguyen et al. (2010) study under dry conditions. However, different from SCI based oligomers, the ratios of $\mathrm{CH}_{2}$ and $\mathrm{CH}_{2} \mathrm{O}$ based oligomers decreased by 18 and $14 \%$ as RH increased from 7 to $85 \%$, respectively. Thus, the reduction of SCI based oligomers is the major reason for the decrease in SOA yields from isoprene- $\mathrm{NO}_{2}$ photooxidations.

\subsection{Mechanisms for the different roles of water in isoprene- $\mathrm{NO}_{2}$ systems}

\subsubsection{Vapor wall loss vs. SCI- $\mathrm{H}_{2} \mathrm{O}$ reaction}

It is noted that the wall loss of semi-volatile organic compounds (SVOCs) can lead to the underestimation of the yield of SOA (Matsunaga and Ziemann, 2010; Loza et al., 2010; Zhang et al., 2014; Yeh and Ziemann, 2015; Ye et al., 2016; Palm et al., 2016; Krechmer et al., 2016; La et al., 2016; Nah et al., 2017). Since SCI-derived oligomers are the major products of $\mathrm{SOA}$ from isoprene- $\mathrm{NO}_{2}$ irradiations, a question arises about which process is dominant for the reduction of SOA production under humid condition, wall loss of SCI related oligomers (in gas phase), or the reaction between SCI and $\mathrm{H}_{2} \mathrm{O}$. The MCM simulation shows that SCIs are so reactive that most of them are consumed by reactions before they are lost to the wall (Fig. 14). The percentage of the SCIs consumed by $\mathrm{H}_{2} \mathrm{O}$ was increased from 6 to $46 \%$ as $\mathrm{RH}$ increased from 5 to $85 \%$ due to the extremely high concentration of gas $\mathrm{H}_{2} \mathrm{O}$. The removal of SCIs by $\mathrm{H}_{2} \mathrm{O}(85 \% \mathrm{RH})$ can lead to a decrease in SCI-derived oligomers by $43 \%$ as compared to $5 \% \mathrm{RH}$. The result is comparable with the decrease in SOA yields of $62 \%$ from isoprene- $\mathrm{NO}_{2}$ irradiations. Meanwhile, as discussed in the previous section, the vapor pressures of SCI-derived oligomers were so low that they were ready to condense on particles. The upper limit of the wall loss rate 


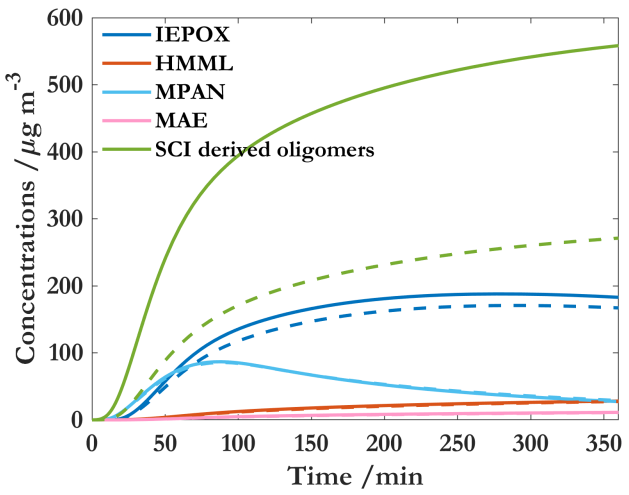

Figure 13. MCM-simulated time profiles of SOA precursors in isoprene- $\mathrm{NO}_{2}$ irradiations. SCI-derived oligomers were from the reactions of SCIs with glyoxylic acid and ACETOL (solid lines for dry conditions, dashed lines for humid conditions).

constant of $4.8 \times 10^{-4} \mathrm{~s}^{-1}$ for SVOC was calculated from the equation given by McMurry and Grosjean (1985), while the condensation rate constant of SVOC to the particles was calculated to be over $0.65 \mathrm{~s}^{-1}$ in our study based on the equation from La et al. (2016). This indicates that the condensation rate of gas-phase oligomers to particles is much faster than that to the wall. Therefore, the reactions between SCIs and $\mathrm{H}_{2} \mathrm{O}$ rather than the wall loss of SVOC are the major cause of the decrease in SOA formation from isoprene- $\mathrm{NO}_{2}$ irradiations in this work.

\subsubsection{Effects of water on $\mathrm{SOA}$ formation: $\mathrm{O}_{3} \mathrm{vs.} \mathrm{OH}$}

To quantify the RH effect of SOA and relatively possible contribution of SCI-derived oligomers from isoprene- $\mathrm{NO}_{2}$ irradiations, the reactions of SCIs with formic acid, glyoxylic acid, and ACETOL were added into MCM, in which the reaction of SCIs with formic acid does not form oligomers. Simulations show that the total mass concentration of oligomers from these reactions was $558.4(271.2) \mu \mathrm{g} \mathrm{m}^{-3}$ at $7 \%(80 \%)$ $\mathrm{RH}$, and the mass concentrations from other SOA precursors IEPOX, MPAN, HMML, and MAE were 182.8 (167.0), 27.4 (28.9), 28.1 (27.4), and $11.2(10.9) \mu \mathrm{g} \mathrm{m}^{-3}$ at $7 \%$ (80\%) RH (Fig. 13). It is obvious that the mass concentrations of SCI-derived oligomers reduced by $51 \%$ as $\mathrm{RH}$ increased from 7 to $80 \%$, while the concentrations of other precursors had little change under different RH conditions. Thus, SCIderived oligomers should have a great potential for formation of SOA, compared to other precursors.

Our results clearly show that the different effects of RH on SOA yields originate from the oxidation channels (Fig. 15). Both the $\mathrm{OH}$ and $\mathrm{O}_{3}$ channels can well explain the differences in results of isoprene- $\mathrm{NO}_{2}$ irradiations from the Zhang et al. (2011) and Nguyen et al. (2011b) studies. In the Zhang et al. (2011) study, there were no additional $\mathrm{OH}$ radical sources in their systems. Thus, the SOA was mainly from the $\mathrm{O}_{3}$ channel. Similar to our isoprene- $\mathrm{O}_{3}$ systems, a neg-

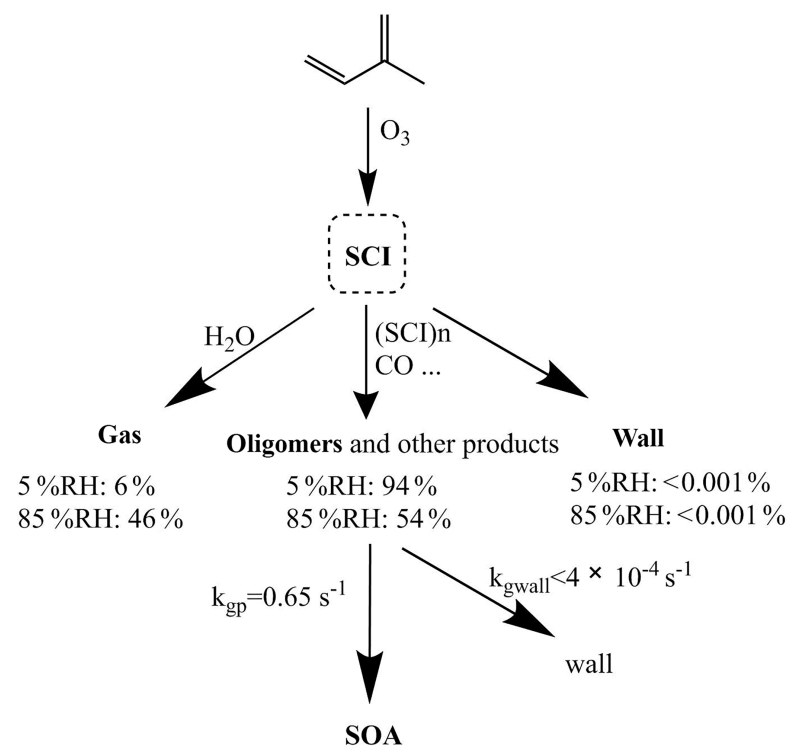

Figure 14. Wall losses vs. gas-phase reactions between $\mathrm{H}_{2} \mathrm{O}$ and SCIs.

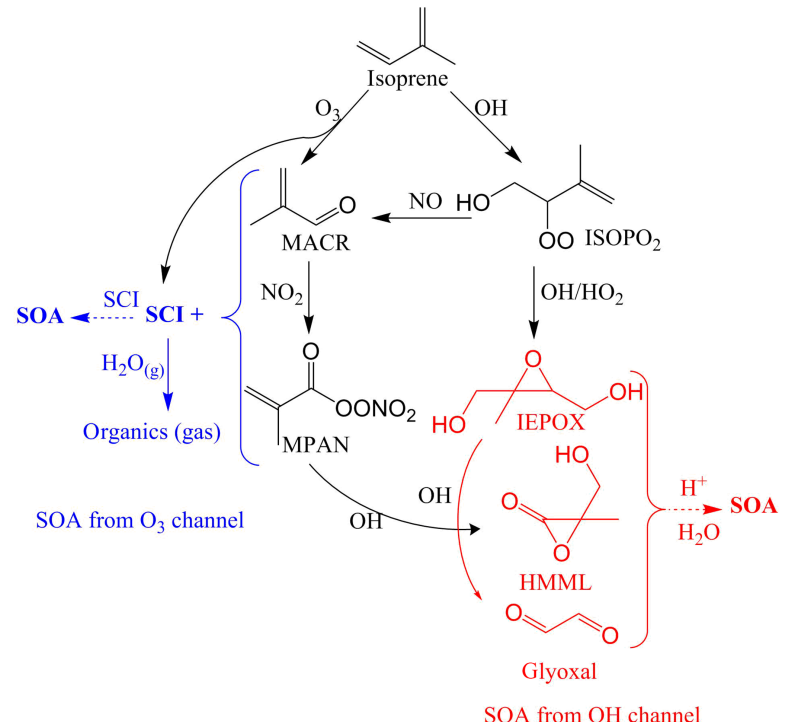

Figure 15. Mechanisms for $\mathrm{SOA}$ formation from the $\mathrm{O}_{3}$ and $\mathrm{OH}$ oxidation channels of isoprene.

ative effect of humidity on SOA yield was observed in their work. In the Nguyen et al. (2011b) work, due to sufficient OH radical source, over $99 \%$ of isoprene was oxidized by $\mathrm{OH}$, and SCI concentrations were very low. Even though high $\mathrm{NO}_{x}$ was used, most MPAN could be further oxidized by $\mathrm{OH}$ to produce epoxides. Therefore, SOA was mainly from the $\mathrm{OH}$ channel in Nguyen et al. (2011b)'s work. This is why the yield of SOA in their work was not influenced by $\mathrm{RH}$. Our results obviously show that SOA is formed by reactive uptake of SOA precursors (e.g., IEPOX) in the $\mathrm{OH}$ channel, and by the condensation of SCI-derived oligomers 
in the $\mathrm{O}_{3}$ channel. In the presence of $\mathrm{NO}_{2}$, the formation of SOA is also controlled by the SCI-related reactions without extra OH sources. However, the SCI-related reactions (SCIderived oligomers) can be inhibited by high water vapor. In previous studies, SOA was usually modeled based on the vapor pressures of SVOC, which only considers the effect of temperature. Our study strongly suggests that $\mathrm{RH}$ is also a key factor in SOA formation.

\section{Conclusion}

Opposite effects of RH on SOA formation from the irradiations of toluene and isoprene have been elucidated in our work. Different influences of RH on both SOA yields and mean molecule size demonstrate the different mechanisms related to SOA formation from the irradiations of toluene and isoprene. High RH can greatly enhance the SOA formation in the toluene- $\mathrm{NO}_{2}$ system, so that the maximum yields of SOA from toluene increased from $5.58 \%$ (dry) to $8.97 \%$ (humid). FTIR spectra show that the increased part of SOA under humid conditions was mainly contributed by aqueous reactions of water-soluble products (e.g., glyoxal). Different from toluene- $\mathrm{NO}_{2}$ irradiations, water has a complex role in isoprene systems. In isoprene- $\mathrm{H}_{2} \mathrm{O}_{2}$ irradiation systems, $\mathrm{RH}$ has no remarkable effects on SOA yields. FTIR spectra show that water can inhibit the oligomerization reactions from polyalcohols; however, polyalcohols were still the major products in both dry and humid conditions from isoprene- $\mathrm{H}_{2} \mathrm{O}_{2}$ irradiation, which was mainly from the reactive uptake of IEPOX in the presence of $\mathrm{H}_{2} \mathrm{SO}_{4}$ particles from background gas. In isoprene- $\mathrm{O}_{3}$ and isoprene- $\mathrm{NO}_{2}$ irradiation systems, high $\mathrm{RH}$ has a negative effect on SOA yields, which decreased from $3.14 \%$ (dry) to $1.19 \%$ (humid). According to the FTIR, ESIHRMS, KMD analysis and MCM simulations, the oligomers with SCIs as base units were considered to be the major products of SOA in isoprene- $\mathrm{O}_{3}$ systems and isoprene- $\mathrm{NO}_{2}$ irradiation systems. Under humid conditions, the SCIs can be consumed by water in the gas phase, leading to the decrease in the formation of oligomers from SCIs.

Data availability. Data are available by contacting the corresponding author.

Competing interests. The authors declare that they have no conflict of interest.

Acknowledgements. This work was supported by the National Natural Science Foundation of China (no. 41375129) and the National Key R\&D Program of China (2017YFC0210005).

Edited by: Jason Surratt

Reviewed by: two anonymous referees

\section{References}

Aklilu, Y. A. and Mozurkewich, M.: Determination of external and internal mixing of organic and inorganic aerosol components from hygroscopic properties of submicrometer particles during a field study in the lower fraser valley, Aerosol Sci. Techn., 38, 140-154, https://doi.org/10.1080/02786820490251367, 2004.

Bonn, B. and Moorgat, G. K.: New particle formation during $\alpha$ - and $\beta$-pinene oxidation by $\mathrm{O}_{3}, \mathrm{OH}$ and $\mathrm{NO}_{3}$, and the influence of water vapour: particle size distribution studies, Atmos. Chem. Phys., 2, 183-196, https://doi.org/10.5194/acp-2183-2002, 2002.

Boyd, C. M., Sanchez, J., Xu, L., Eugene, A. J., Nah, T., Tuet, W. Y., Guzman, M. I., and Ng, N. L.: Secondary organic aerosol formation from the $\beta$-pinene $+\mathrm{NO}_{3}$ system: effect of humidity and peroxy radical fate, Atmos. Chem. Phys., 15, 7497-7522, https://doi.org/10.5194/acp-15-7497-2015, 2015.

Calogirou, A., Larsen, B. R., and Kotzias, D.: Gas-phase terpene oxidation products: A review, Atmos. Environ., 33, 1423-1439, https://doi.org/10.1016/S1352-2310(98)00277-5, 1999.

Calvert, J. G., Atkinson, R., Kerr, J. A., Madronich, S., Moortgat, G. K., Wallington, T. J., and Yarwood, G.: The mechanisms of atmospheric oxidation of the alkenes, Oxford University Press, Oxford, 2000.

Carlton, A. G., Wiedinmyer, C., and Kroll, J. H.: A review of Secondary Organic Aerosol (SOA) formation from isoprene, Atmos. Chem. Phys., 9, 4987-5005, https://doi.org/10.5194/acp-9-49872009, 2009.

Chao, W., Hsieh, J. T., Chang, C. H., and Lin, J. J. M.: Direct kinetic measurement of the reaction of the simplest Criegee intermediate with water vapor, Science, 347, 751-754, https://doi.org/10.1126/science.1261549, 2015.

Clark, C. H., Kacarab, M., Nakao, S., Asa-Awuku, A., Sato, K., and Cocker, D. R.: Temperature effects on secondary organic aerosol (SOA) from the dark ozonolysis and photooxidation of isoprene, Environ. Sci. Technol., 50, 5564-5571, https://doi.org/10.1021/acs.est.5b05524, 2016.

Cocker, D. R., Mader, B. T., Kalberer, M., Flagan, R. C., and Seinfeld, J. H.: The effect of water on gas-particle partitioning of secondary organic aerosol: II. m-xylene and 1,3,5trimethylbenzene photooxidation systems, Atmos. Environ., 35, 6073-6085, https://doi.org/10.1016/S1352-2310(01)004058, 2001

Czoschke, N. M., Jang, M., and Kamens, R. M.: Effect of acidic seed on biogenic secondary organic aerosol growth, Atmos. Environ., 37, 4287-4299, https://doi.org/10.1016/S13522310(03)00511-9, 2003.

Dommen, J., Metzger, A., Duplissy, J., Kalberer, M., Alfarra, M. R., Gascho, A., Weingartner, E., Prevot, A. S. H., Verheggen, B., and Baltensperger, U.: Laboratory observation of oligomers in the aerosol from isoprene/ $\mathrm{NO}_{x}$ photooxidation, Geophys. Res. Lett., 33, L13805, https://doi.org/10.1029/2006GL026523, 2006.

Duarte, R. M. B. O., Pio, C. A., and Duarte, A. C.: Spectroscopic study of the water-soluble organic matter isolated from atmospheric aerosols collected under different atmospheric conditions, Anal. Chim. Acta, 530, 7-14, https://doi.org/10.1016/j.aca.2004.08.049, 2005.

Engelhart, G. J., Hildebrandt, L., Kostenidou, E., Mihalopoulos, N., Donahue, N. M., and Pandis, S. N.: Water con- 
tent of aged aerosol, Atmos. Chem. Phys., 11, 911-920, https://doi.org/10.5194/acp-11-911-2011, 2011.

Ervens, B., Turpin, B. J., and Weber, R. J.: Secondary organic aerosol formation in cloud droplets and aqueous particles (aqSOA): a review of laboratory, field and model studies, Atmos. Chem. Phys., 11, 11069-11102, https://doi.org/10.5194/acp-1111069-2011, 2011.

Fry, J. L., Kiendler-Scharr, A., Rollins, A. W., Wooldridge, P. J., Brown, S. S., Fuchs, H., Dubé, W., Mensah, A., dal Maso, M., Tillmann, R., Dorn, H.-P., Brauers, T., and Cohen, R. C.: Organic nitrate and secondary organic aerosol yield from $\mathrm{NO}_{3}$ oxidation of $\beta$-pinene evaluated using a gas-phase kinetics/aerosol partitioning model, Atmos. Chem. Phys., 9, 14311449, https://doi.org/10.5194/acp-9-1431-2009, 2009.

Gaston, C. J., Riedel, T. P., Zhang, Z. F., Gold, A., Surratt, J. D., and Thornton, J. A.: Reactive uptake of an isoprene-derived epoxydiol to submicron aerosol particles, Environ. Sci. Technol., 48, 11178-11186, https://doi.org/10.1021/es5034266, 2014.

Ge, S. S., Xu, Y. F., and Jia, L.: Secondary organic aerosol formation from propylene irradiations in a chamber study, Atmos. Environ., 157, 146-155, https://doi.org/10.1016/j.atmosenv.2017.03.019, 2017.

Healy, R. M., Temime, B., Kuprovskyte, K., and Wenger, J. C.: Effect of relative humidity on gas/particle partitioning and aerosol mass yield in the photooxidation of $p$-xylene, Environ. Sci. Technol., 43, 1884-1889, https://doi.org/10.1021/es802404z, 2009.

Hildebrandt, L., Donahue, N. M., and Pandis, S. N.: High formation of secondary organic aerosol from the photooxidation of toluene, Atmos. Chem. Phys., 9, 2973-2986, https://doi.org/10.5194/acp-9-2973-2009, 2009.

Hsu, C. S., Qian, K., and Chen, Y. C.: An innovative approach to data analysis in hydrocarbon characterization by on-line liquid chromatography-mass spectrometry, Anal. Chim. Acta, 264, 7989, https://doi.org/10.1016/0003-2670(92)85299-L, 1992.

Inomata, S., Sato, K., Hirokawa, J., Sakamoto, Y., Tanimoto, H., Okumura, M., Tohno, S., and Imamura, T.: Analysis of secondary organic aerosols from ozonolysis of isoprene by proton transfer reaction mass spectrometry, Atmos. Environ., 97, 397-405, https://doi.org/10.1016/j.atmosenv.2014.03.045, 2014.

Jenkin, M. E., Young, J. C., and Rickard, A. R.: The MCM v3.3.1 degradation scheme for isoprene, Atmos. Chem. Phys., 15, 11433-11459, https://doi.org/10.5194/acp-15-11433-2015, 2015.

Jia, L. and $\mathrm{Xu}, \mathrm{Y}$. F.: Effects of relative humidity on ozone and secondary organic aerosol formation from the photooxidation of benzene and ethylbenzene, Aerosol Sci. Technol., 48, 1-12, https://doi.org/10.1080/02786826.2013.847269, 2014.

Jia, L. and $\mathrm{Xu}, \mathrm{Y}$. F.: Ozone and secondary organic aerosol formation from Ethylene- $\mathrm{NO}_{x}-\mathrm{NaCl}$ irradiations under different relative humidity conditions, J. Atmos. Chem., 73, 81-100, https://doi.org/10.1007/s10874-015-9317-1, 2016.

Jimenez, J. L., Canagaratna, M. R., Donahue, N. M., Prevot, A. S. H., Zhang, Q., Kroll, J. H., DeCarlo, P. F., Allan, J. D., Coe, H., Ng, N. L., Aiken, A. C., Docherty, K. S., Ulbrich, I. M., Grieshop, A. P., Robinson, A. L., Duplissy, J., Smith, J. D., Wilson, K. R., Lanz, V. A., Hueglin, C., Sun, Y. L., Tian, J., Laaksonen, A., Raatikainen, T., Rautiainen, J., Vaattovaara, P., Ehn, M., Kulmala, M., Tomlinson, J. M., Collins, D. R., Cubison, M. J., Dunlea, J., Huffman, J. A., Onasch, T. B., Al- farra, M. R., Williams, P. I., Bower, K., Kondo, Y., Schneider, J., Drewnick, F., Borrmann, S., Weimer, S., Demerjian, K., Salcedo, D., Cottrell, L., Griffin, R., Takami, A., Miyoshi, T., Hatakeyama, S., Shimono, A., Sun, J. Y., Zhang, Y. M., Dzepina, K., Kimmel, J. R., Sueper, D., Jayne, J. T., Herndon, S. C., Trimborn, A. M., Williams, L. R., Wood, E. C., Middlebrook, A. M., Kolb, C. E., Baltensperger, U., and Worsnop, D. R.: Evolution of organic aerosols in the atmosphere, Science, 326, 1525-1529, https://doi.org/10.1126/science.1180353, 2009.

Kalberer, M., Paulsen, D., Sax, M., Steinbacher, M., Dommen, J., Prevot, A. S. H., Fisseha, R., Weingartner, E., Frankevich, V., Zenobi, R. and Baltensperger, U.: Identification of polymers as major components of atmospheric organic aerosols, Science, 303, 1659-1662, https://doi.org/10.1126/science.1092185, 2004.

Kamens, R., Jang, M., Chien, C. J., and Leach, K.: Aerosol formation from the reaction of $\alpha$-pinene and ozone using a gas-phase kinetics-aerosol partitioning model, Environ. Sci. Technol., 33, 1430-1438, https://doi.org/10.1021/es980725r, 1999.

Kamens, R. M., Zhang, H. F., Chen, E. H., Zhou, Y., Parikh, H. M., Wilson, R. L., Galloway, K. E., and Rosen, E. P.: Secondary organic aerosol formation from toluene in an atmospheric hydrocarbon mixture: Water and particle seed effects, Atmos. Environ., 45, 2324-2334, https://doi.org/10.1016/j.atmosenv.2010.11.007, 2011.

Kendrick, E.: A mass scale based on $\mathrm{CH}_{2}=14.0000$ for high resolution mass spectrometry of organic compounds, Anal. Chem. 35, 2146-2154, https://doi.org/10.1021/ac60206a048, 1963.

Krechmer, J. E., Pagonis, D., Ziemann, P. J., and Jimenez, J. L.: Quantification of gas-wall partitioning in teflon environmental chambers using rapid bursts of low-volatility oxidized species generated in situ, Environ. Sci. Technol., 50, 5757-5765, https://doi.org/10.1021/acs.est.6b00606, 2016.

La, Y. S., Camredon, M., Ziemann, P. J., Valorso, R., Matsunaga, A., Lannuque, V., Lee-Taylor, J., Hodzic, A., Madronich, S., and Aumont, B.: Impact of chamber wall loss of gaseous organic compounds on secondary organic aerosol formation: explicit modeling of SOA formation from alkane and alkene oxidation, Atmos. Chem. Phys., 16, 1417-1431, https://doi.org/10.5194/acp16-1417-2016, 2016.

Lewandowski, M., Jaoui, M., Offenberg, J. H., Krug, J. D., and Kleindienst, T. E.: Atmospheric oxidation of isoprene and 1,3butadiene: influence of aerosol acidity and relative humidity on secondary organic aerosol, Atmos. Chem. Phys., 15, 3773-3783, https://doi.org/10.5194/acp-15-3773-2015, 2015.

Lim, Y. B., Tan, Y., Perri, M. J., Seitzinger, S. P., and Turpin, B. J.: Aqueous chemistry and its role in secondary organic aerosol (SOA) formation, Atmos. Chem. Phys., 10, 1052110539, https://doi.org/10.5194/acp-10-10521-2010, 2010.

Lim, Y. B., Tan, Y., and Turpin, B. J.: Chemical insights, explicit chemistry, and yields of secondary organic aerosol from $\mathrm{OH}$ radical oxidation of methylglyoxal and glyoxal in the aqueous phase, Atmos. Chem. Phys., 13, 8651-8667, https://doi.org/10.5194/acp-13-8651-2013, 2013.

Lin, Y. H., Zhang, Z. F., Docherty, K. S., Zhang, H. F., Budisulistiorini, S. H., Rubitschun, C. L., Shaw, S. L., Knipping, E. M., Edgerton, E. S., Kleindienst, T. E., Gold, A., and Surratt, J. D.: Isoprene epoxydiols as precursors to secondary organic aerosol formation: Acid-catalyzed reactive uptake studies 
with authentic compounds, Environ. Sci. Technol., 46, 250-258, https://doi.org/10.1021/es202554c, 2012.

Lin, Y. H., Zhang, H. F., Pye, H. O. T., Zhang, Z. F., Marth, W. J., Park, S., Arashiro, M., Cui, T., Budisulistiorini, S. H., Sexton, K. G., Vizuete, W., Xie, Y., Luecken, D. J., Piletic, I. R., Edney, E. O., Bartolotti, L. J., Gold, A., and Surratt, J. D.: Epoxide as a precursor to secondary organic aerosol formation from isoprene photooxidation in the presence of nitrogen oxides, P. Natl. Acad. Sci. USA, 110, 6718-6723, https://doi.org/10.1073/pnas.1221150110, 2013.

Lin, Y. H., Budisulistiorini, S. H., Chu, K., Siejack, R. A., Zhang, H. F., Riva, M., Zhang, Z. F., Gold, A., Kautzman, K. E., and Surratt, J. D.: Light-absorbing oligomer formation in secondary organic aerosol from reactive uptake of isoprene epoxydiols, Environ. Sci. Technol., 48, 12012-12021, https://doi.org/10.1021/es503142b, 2014.

Liu, S., Shilling, J. E., Song, C., Hiranuma, N., Zaveri, R. A., and Russell, L. M.: Hydrolysis of organonitrate functional groups in aerosol particles, Aerosol Sci. Technol., 46, 1359-1369, https://doi.org/10.1080/02786826.2012.716175, 2012.

Loza, C. L., Chan, A. W. H., Galloway, M. M., Keutsch, F. N., Flagan, R. C., and Seinfeld, J. H.: Characterization of vapor wall loss in laboratory chambers, Environ. Sci. Technol., 44, 5074-5078, https://doi.org/10.1021/es100727v, 2010.

Matsunaga, A. and Ziemann, P. J.: Gas-wall partitioning of organic compounds in a teflon film chamber and potential effects on reaction product and aerosol yield measurements, Aerosol Sci. Tech., 44, 881-892, https://doi.org/10.1080/02786826.2010.501044, 2010

Mostafa, S., Korak, J. A., Shimabuku, K., Glover, C. M., and Rosario-Ortiz, F. L.: Relation between optical properties and formation of reactive intermediates from different size fractions of organic matter, ACS Symposium Series, 1160, 159-179, 2014.

Nah, T., McVay, R. C., Pierce, J. R., Seinfeld, J. H., and Ng, N. L.: Constraining uncertainties in particle-wall deposition correction during SOA formation in chamber experiments, Atmos. Chem. Phys., 17, 2297-2310, https://doi.org/10.5194/acp17-2297-2017, 2017.

Ng, N. L., Kroll, J. H., Chan, A. W. H., Chhabra, P. S., Flagan, R. C., and Seinfeld, J. H.: Secondary organic aerosol formation from m-xylene, toluene, and benzene, Atmos. Chem. Phys., 7, 3909-3922, https://doi.org/10.5194/acp-7-3909-2007, 2007.

Nguyen, T. B., Bateman, A. P., Bones, D. L., Nizkorodov, S. A., Laskin, J., and Laskin, A.: High-resolution mass spectrometry analysis of secondary organic aerosol generated by ozonolysis of isoprene, Atmos. Environ., 44, 1032-1042, https://doi.org/10.1016/j.atmosenv.2009.12.019, 2010.

Nguyen, T. B., Laskin, J., Laskin, A., and Nizkorodov, S. A.: Nitrogen-containing organic compounds and oligomers in secondary organic aerosol formed by photooxidation of isoprene, Environ. Sci. Technol., 45, 6908-6918, https://doi.org/10.1021/es201611n, 2011a.

Nguyen, T. B., Roach, P. J., Laskin, J., Laskin, A., and Nizkorodov, S. A.: Effect of humidity on the composition of isoprene photooxidation secondary organic aerosol, Atmos. Chem. Phys., 11, 6931-6944, https://doi.org/10.5194/acp-11-6931-2011, 2011 b.

Nguyen, T. B., Coggon, M. M., Bates, K. H., Zhang, X., Schwantes, R. H., Schilling, K. A., Loza, C. L., Flagan, R. C., Wennberg, P. O., and Seinfeld, J. H.: Organic aerosol formation from the reactive uptake of isoprene epoxydiols (IEPOX) onto nonacidified inorganic seeds, Atmos. Chem. Phys., 14, 3497-3510, https://doi.org/10.5194/acp-14-3497-2014, 2014.

Nguyen, T. B., Bates, K. H., Crounse, J. D., Schwantes, R. H., Zhang, X., Kjaergaard, H. G., Surratt, J. D., Lin, P., Laskin, A., Seinfeld, J. H., and Wennberg, P. O.: Mechanism of the hydroxyl radical oxidation of methacryloyl peroxynitrate (MPAN) and its pathway toward secondary organic aerosol formation in the atmosphere, Phys. Chem. Chem. Phys., 17, 17914-17926, https://doi.org/10.1039/C5CP02001H, 2015.

Nizkorodov, S. A., Laskin, J., and Laskin, A.: Molecular chemistry of organic aerosols through the application of high resolution mass spectrometry, Phys. Chem. Chem. Phys., 13, 3612-3629, https://doi.org/10.1039/c0cp02032j, 2011.

Odum, J. R., Jungkamp, T. P. W., Griffin, R. J., Flagan, R. C., and Seinfeld, J. H.: The atmospheric aerosol-forming potential of whole gasoline vapor, Science, 276, 96-99, https://doi.org/10.1126/science.276.5309.96, 1997.

Palm, B. B., Campuzano-Jost, P., Ortega, A. M., Day, D. A., Kaser, L., Jud, W., Karl, T., Hansel, A., Hunter, J. F., Cross, E. S., Kroll, J. H., Peng, Z., Brune, W. H., and Jimenez, J. L.: In situ secondary organic aerosol formation from ambient pine forest air using an oxidation flow reactor, Atmos. Chem. Phys., 16, 2943 2970, https://doi.org/10.5194/acp-16-2943-2016, 2016.

Pankow, J. F. and Asher, W. E.: SIMPOL.1: a simple group contribution method for predicting vapor pressures and enthalpies of vaporization of multifunctional organic compounds, Atmos. Chem. Phys., 8, 2773-2796, https://doi.org/10.5194/acp-8-27732008, 2008.

Peuravuori, J. and Pihlaja, K.: Molecular size distribution and spectroscopic properties of aquatic humic substances, Anal. Chim. Acta, 337, 133-149, https://doi.org/10.1016/S00032670(96)00412-6, 1997.

Prenni, A. J., Petters, M. D., Kreidenweis, S. M., DeMott, P. J., and Ziemann, P. J.: Cloud droplet activation of secondary organic aerosol, J. Geophys. Res., 112, D10223, https://doi.org/10.1029/2006JD007963, 2007.

Pretsch, E., Buhlmann, P., and Badertscher, M.: Structure determination of organic compounds, 4th Edn., Springer Berlin Heidelberg, Berlin, Heidelberg, 291 pp., 2009.

Reinhardt, A., Emmenegger, C., Gerrits, B., Panse, C., Dommen, J., Baltensperger, U., Zenobi, R., and Kalberer, M.: Ultrahigh mass resolution and accurate mass measurements as a tool to characterize oligomers in secondary organic aerosols, Anal. Chem., 79, 4074-4082, https://doi.org/10.1021/ac062425v, 2007.

Riedel, T. P., Lin, Y. H., Budisulistiorini, S. H., Gaston, C. J., Thornton, J. A., Zhang, Z. F., Vizuete, W., Gold, A., and Surratt, J. D.: Heterogeneous reactions of isoprene-derived epoxides: Reaction probabilities and molar secondary organic aerosol yield estimates, Environ. Sci. Technol. Let., 2, 38-42, https://doi.org/10.1021/ez500406f, 2015.

Riva, M., Bell, D. M., Hansen, A.-M. K., Drozd, G. T., Zhang, Z. F., Gold, A., Imre, D., Surratt, J. D., Glasius, M., and Zelenyuk, A.: Effect of organic coatings, humidity and aerosol acidity on multiphase chemistry of isoprene epoxydiols, Environ. Sci. Technol., 50, 5580-5588, https://doi.org/10.1021/acs.est.5b06050, 2016.

Riva, M., Budisulistiorini, S. H., Zhang, Z. F., Gold, A., Thornton, J. A., Turpin, B. J., and Surratt, J. D.: Multiphase reactivity of gaseous hydroperoxide oligomers produced from isoprene 
ozonolysis in the presence of acidified aerosols, Atmos. Environ., 152, 314-322, https://doi.org/10.1016/j.atmosenv.2016.12.040, 2017.

Sadezky, A., Chaimbault, P., Mellouki, A., Römpp, A., Winterhalter, R., Le Bras, G., and Moortgat, G. K.: Formation of secondary organic aerosol and oligomers from the ozonolysis of enol ethers, Atmos. Chem. Phys., 6, 5009-5024, https://doi.org/10.5194/acp6-5009-2006, 2006.

Sadezky, A., Winterhalter, R., Kanawati, B., Römpp, A., Spengler, B., Mellouki, A., Le Bras, G., Chaimbault, P., and Moortgat, G. K.: Oligomer formation during gas-phase ozonolysis of small alkenes and enol ethers: new evidence for the central role of the Criegee Intermediate as oligomer chain unit, Atmos. Chem. Phys., 8, 2667-2699, https://doi.org/10.5194/acp-8-2667-2008, 2008.

Sakamoto, Y., Inomata, S., and Hirokawa, J.: Oligomerization reaction of the criegee intermediate leads to secondary organic aerosol formation in ethylene ozonolysis, J. Phys. Chem. A, 117, 12912-12921, https://doi.org/10.1021/jp408672m, 2013.

Shen, X. L., Wu, H. H., Zhao, Y., Huang, D., Huang, L. B., and Chen, Z. M.: Heterogeneous reactions of glyoxal on mineral particles: A new avenue for oligomers and organosulfate formation, Atmos. Environ., 131, 133-140, https://doi.org/10.1016/j.atmosenv.2016.01.048, 2016.

Song, C., Na, K., Warren, B., Malloy, Q., and Cocker, D. R.: Impact of propene on secondary organic aerosol formation from m-Xylene, Environ. Sci. Technol., 41, 6990-6995, https://doi.org/10.1021/es062279a, 2007.

Stroud, C. A., Makar, P. A., Michelangeli, D. V., Mozurkewich, M., Hastie, D. R., Barbu, A., and Humble, J.: Simulating organic aerosol formation during the photooxidation of toluene/ $\mathrm{NO}_{x}$ mixtures: comparing the equilibrium and kinetic assumption, Environ. Sci. Technol., 38, 1471-1479, https://doi.org/10.1021/es030546w, 2004.

Surratt, J. D., Chan, A. W. H., Eddingsaas, N. C., Chan, M. N., Loza, C. L., Kwan, A. J., Hersey, S. P., Flagan, R. C., Wennberg, P. O., and Seinfeld, J. H.: Reactive intermediates revealed in secondary organic aerosol formation from isoprene, P. Natl. Acad. Sci. USA, 107, 6640-6645, https://doi.org/10.1073/pnas.0911114107, 2010.

Tobias, H. J. and Ziemann, P. J.: Kinetics of the gas-phase reactions of alcohols, aldehydes, carboxylic acids, and water with the C13 stabilized criegee intermediate formed from ozonolysis of 1-tetradecene, J. Phys. Chem. A, 105, 6129-6135, https://doi.org/10.1021/jp004631r, 2001.

Vereecken, L., Harder, H., and Novelli, A.: The reaction of Criegee intermediates with $\mathrm{NO}, \mathrm{RO}_{2}$, and $\mathrm{SO}_{2}$, and their fate in the atmosphere, Phys. Chem. Chem. Phys., 14, 14682-14695, https://doi.org/10.1039/c2cp42300f, 2012.

Volkamer, R., Ziemann, P. J., and Molina, M. J.: Secondary Organic Aerosol Formation from Acetylene $\left(\mathrm{C}_{2} \mathrm{H}_{2}\right)$ : seed effect on SOA yields due to organic photochemistry in the aerosol aqueous phase, Atmos. Chem. Phys., 9, 1907-1928, https://doi.org/10.5194/acp-9-1907-2009, 2009.

Walser, M. L., Desyaterik, Y., Laskin, J., Laskin, A., and Nizkorodov, S. A.: High-resolution mass spectrometric analysis of secondary organic aerosol produced by ozonation of limonene, Phys. Chem. Chem. Phys., 10, 1009-1022, https://doi.org/10.1039/B712620D, 2008.
Wang, Y. J., Luo, H., Jia, L., and Ge, S. S.: Effect of particle water on ozone and secondary organic aerosol formation from benzene- $\mathrm{NO}_{2}-\mathrm{NaCl}$ irradiations, Atmos. Environ., 140, 386394, https://doi.org/10.1016/j.atmosenv.2016.06.022, 2016.

White, S. J., Jamie, I. M., and Angove, D. E.: Chemical characterisation of semi-volatile and aerosol compounds from the photooxidation of toluene and $\mathrm{NO}_{x}$, Atmos. Environ., 83, 237-244, https://doi.org/10.1016/j.atmosenv.2013.11.023, 2014.

Ye, P. L., Ding, X., Hakala, J., Hofbauer, V., Robinson, E. S., and Donahue, N. M.: Vapor wall loss of semi-volatile organic compounds in a Teflon chamber, Aerosol Sci. Tech., 50, 822-834, https://doi.org/10.1080/02786826.2016.1195905, 2016.

Yeh, G. K. and Ziemann, P. J.: Gas-wall partitioning of oxygenated organic compounds: measurements, structureactivity relationships, and correlation with gas chromatographic retention factor, Aerosol Sci. Tech., 49, 727-738, https://doi.org/10.1080/02786826.2015.1068427, 2015.

Zhang, H., Surratt, J. D., Lin, Y. H., Bapat, J., and Kamens, R. M.: Effect of relative humidity on SOA formation from isoprene/NO photooxidation: enhancement of 2-methylglyceric acid and its corresponding oligoesters under dry conditions, Atmos. Chem. Phys., 11, 6411-6424, https://doi.org/10.5194/acp11-6411-2011, 2011.

Zhang, H. F., Lin, Y. H., Zhang, Z. F., Zhang, X. L., Shaw, S. L., Knipping, E. M., Weber, R. J., Gold, A., Kamens, R. M., and Surratt, J. D.: Secondary organic aerosol formation from methacrolein photooxidation: Roles of NOx level, relative humidity and aerosol acidity, Environ. Chem., 9, 247-262, https://doi.org/10.1071/EN12004, 2012.

Zhang, X., Cappa, C. D., Jathar, S. H., McVay, R. C., Ensberg, J. J., Kleeman, M. J., and Seinfeld, J. H.: Influence of vapor wall loss in laboratory chambers on yields of secondary organic aerosol, P. Natl. Acad. Sci. USA, 111, 5802-5807, https://doi.org/10.1073/pnas.1404727111, 2014.

Zhang, Y., Chen, Y. Z., Lambe, A. T., Olson, N. E., Lei, Z. Y., Craig, R. L., Zhang, Z. F., Gold, A., Onasch, T. B., Jayne, J. T., Worsnop, D. R., Gaston, C. J., Thornton, J. A., Vizuete, W., Ault, A. P., and Surratt, J. D.: Effect of the aerosol-phase state on secondary organic aerosol formation from the reactive uptake of isoprene-derived epoxydiols (IEPOX), Environ. Sci. Technol. Let., 5, acs.estlett.8b00044, https://doi.org/10.1021/acs.estlett.8b00044, 2018.

Zhao, Y., Wingen, L. M., Perraud, V., Greaves, J., and FinlaysonPitts, B. J.: Role of the reaction of stabilized Criegee intermediates with peroxy radicals in particle formation and growth in air, Phys. Chem. Chem. Phys., 17, 12500-12514, https://doi.org/10.1039/C5CP01171J, 2015.

Zhao, Y., Wingen, L. M., Perraud, V., and Finlayson-Pitts, B. J.: Phase, composition, and growth mechanism for secondary organic aerosol from the ozonolysis of $\alpha$-cedrene, Atmos. Chem. Phys., 16, 3245-3264, https://doi.org/10.5194/acp-163245-2016, 2016.

Zhou, Y., Zhang, H. F., Parikh, H. M., Chen, E. H., Rattanavaraha, W., Rosen, E. P., Wang, W. X., and Kamens, R. M.: Secondary organic aerosol formation from xylenes and mixtures of toluene and xylenes in an atmospheric urban hydrocarbon mixture: Water and particle seed effects (II), Atmos. Environ., 45, 3882-3890, https://doi.org/10.1016/j.atmosenv.2010.12.048, 2011. 